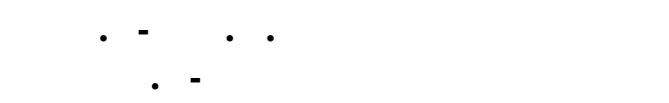

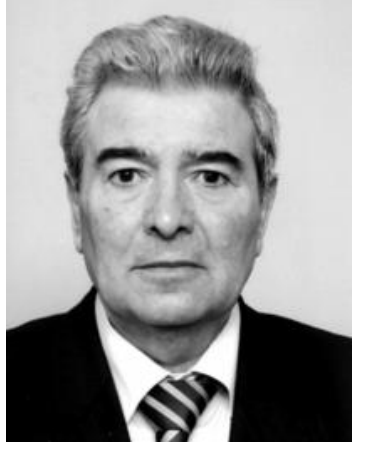

ецензенти: доц. Д-р ик. н. имитър дилов

доц. Д-р л димир л димиров

\section{ьведение}

ъвременн т н ук, в тов число и икономик т, е немислим без м тем тическия п р т. о приложението н м тем тическите методи, и преди всичко н количествените, в конкретн обл ст н зн нието изискв реш в нето н редиц методологични проблеми. предл г ното изследв не вторите си пост вят 3 цел д откроят някои спекти от методологият н м тем тик т ин т зи основ д извед твъзможностите 3 приложимостн м тем тическия п р тв другин уки, в т.ч. и в икономик т , p зглежд н к то теория, политик и пр ктик .

първ т ч ст н студият с изведени и р зглед ни въпроси, свърз ни с осмисляне н $\mathrm{x}$ р ктер и процес н м тем тическото позн ние относно: предметът и особеностите н м тем тик т, видовете бстр кции в м тем тик т, методите н иде лиз ция, форм лиз ция и ксиом тиз ция. Зглед н е специфичн т роля н пр ктик т в р звитието н м тем тик т, критериите 3 истиностт н м тем тическите зн ния, някои з кономерности в историческото р звитие н м тем тик т . т новището н вторите се свежд до следното: м тем тик т тов е н ук 3 построяв нен хипотези, съгл сув ни с н личните зн ния 3 ре лния свят, т.е. м тем тик т е изключително удобн прост сред , в която мог т д се моделир т същностните х р ктеристики н процесите и явленият от з обик лящ т ни действителност.

ъв втор т ч ст н студият се пр ви опит д бъд т изведени предпост вките и възможностите 3 приложение н м тем тическия инструмент риум в икономик т . кономик т е първ т обществен н ук, която з почв д използв широко $\mathrm{p}$ знообр зен п р т. зведени с особеностите н икономическ т н ук, които пр вят този п р т много по-р зличен от м тем тическия п р т н естествените н уки, к то н пример физик т и мех ник т . кцентир се върху тов , че потребностт от специфичен инструмент риум 3 изследв не вътре в с м т икономик , к то н учно зн ние, обусл вя интензивното използв не н м тем тик - 
т в икономичск т теория. зведен е позицият н вторите относно тов , че м тем тическ т интерпрет ция н икономическите идеи е изключително удобен инструмент 3 предл г не и изл г не н едни или други концепции.

звестно е, че прил г нето н м тем тик т в други н уки се изр зяв в построяв нето н м тем тически модели н изуч в ните от тях природни или обществени процеси и явления. ор ди тов в изследв нето се отделя подходящо място н необходимостт от построяв нето, експериментир нето и използв нето н икономико-м тем тически модели н н стоящия ет п от икономическото р звитие, $\mathrm{x}$ р ктерен преди всичко с преход към икономик н зн нието.

м по себе си сфер т н икономико-м тем тичските изследв ния е изключително н ситен, $\mathrm{p}$ знообр зн и обширн, изискв щ 3 дълбочени позн ния и ре лни възможности 3 използв не н приложн т м тем тик, теоретичн т метрик, компютърните технологии, системния н лиз и р збир се, преди всичко н икономическ т теория. този контекст в студият се пр ви опит н 63 т н постигн ти резулт ти д се очерт е нов т концепция з ролят и мястото н икономико-м тем тическите модели в систем т н теоретичните и приложните икономически изследв ния, $\mathrm{p}$ зширяв йки тр диционните предст ви н м тем тическите модели с мо к то инструмент 3 икономически н лиз. вторите не 3 ст в т н позицият 3 отделянето н икономико-м тем тичското моделир не от икономическ т теория, по-скоро тук целт е то д се н пр ви много по-р цион лно и достъпно з повече изследов тели и пр ктици. основ т н всеки икономиком тем тически обект, к кто и в процес н неговото конструир не, интерпретир не, н лизир не и приложение стоят двете вз имосвърз ни съст вки "икономик м тем тическо моделир не". ърв т съст вк "икономик ", възприем н и к то ре лн икономик или нейни компоненти, и к то икономическ теория или други нейни фр гменти, се прием 3 обектн сфер н икономико-м тем тическото моделир не. тор т съст вк "м тем тическо моделир не", включв щ подходящо подбр ни м тем тически конструкции и информ ционни средств, е отнесен до предметн т сфер н икономико-м тем тическите модели.

ч стието н вторите в н стоящото изследв не е, к кто следв : въведение и ч ст първ - проф. Д.ик.н. . т н сов, ч ст втор и з ключение - доц. д-р л мен лиев.

\section{1. якои спекти от методологият н м тем тик т}

\section{1. редмет и особености н м тем тик т}

тем тик т (гръц. $m$ thema - зн ние) "е множество от сложно свърз ни помежду си теории, отлич в щи се с висок степен н отвлеченост и отт м с висок степен н общност"1. всяк н ук, в тов число и м тем тик т , е необходимо д се пост вят въпроси з тов, к кв е нейн т основн цел, К Къв е нейният пред-

1 р тк бълг рск енциклопедия ( ). ом 3. офия: , 1966, с. 365. 
мет, през к кви периоди н р звитие е премин л , к кво изуч в , к къв е кръгът н изследв ните проблеми. поред к демик етър ендеров "основн т цел н м тем тик т не е д открив нови феномени - м к р и тов д се случв, и то много често. ейният принос в зн нието се състои преди всичко в изясняв нето н вз имовръзките между нещ т - кое от к кво з виси, к к се обусл вя, к к д се отсеят съществените от несъществените ф ктори, д се опиш т количествените вз имоотношения. тов , ког то изуч в ме някое явление с м тем тически методи, естествено е д им ме н Й-н пред емпирични резулт ти или д 3 почнем с пр ктическиз д чи"2. Ђпросът 3 предмет иособеностите н м тем тик т к то н ук им принципно зн чение не с моз нейното р звитие, но из пр вилното възприем не н нейното място в обществения живот. особен сил този въпрос стои в случ ите, ког то се появяв т принципно нови теории или методи, допълв щи или опроверг в щи съществув щи т кив в други н учни обл сти, в ч стност в икономическ т теория.

своето р звитие всяк н ук допълв и обог тяв своя предмет, включв в него съсвем нови обл сти н изследв не, извежд ново, зн чително обог тено съдърж ние. по-добро смисляне н предмет н м тем тик т и нейните особености, к кто тов е необходимо з всяк н ук, е целесъобр зно д се използв исторически подход. сторият н м тем тик т предост вя обстоен м тери л 3 възприем нето н тов к к с се формир ли методите н м тем тическото позн ние 3 свет, p зличните видове бстр кции в м тем тик т, основите н м тем тическ т теория, к к с се обог тяв ли и допълв ли с ново съдърж ние основните понятия в м тем тик т, к к в продължение н хилядолетия с се тр нсформир ли възникн ли идеи, к к с времето с се изменяли съдърж нието, х р ктерът и стильт н н учното зн ние. сторическият преглед пок зв , че изведеното определение н м тем тик т се допълв с все по-бог то съдърж ние във връзк с р зширяв нето н обл стт н количествените отношения и простр нствените форми, изуч в ни в м тем тик т, p зглежд н к то "теоретичн н ук, възникн л и р звив л се в н й-дълбок древност във връзк с пр ктическите нужди н човек и непосредственото н блюдение н околния свят" 3 .

сторическият н лиз н постигн тите теоретични резулт ти, ре лизир ните идеи и изведените методи е позволил н учените, изследв ли р звитието н м тем тик т, д обособят следните четири гл вни период ${ }^{4}$ :

- период н 3 р жд нето н м тем тик т ;

- период н елемент рн т м тем тик ;

- период н променливите величини;

- период н съвременн т м тем тик.

2 ендеров, . ръзк т между отделните нещ много често мин в през м тем тик т . ук т новите тенденции. ъст вител икол й теев. вят, 2001, с. 123.

ит. съч., стр. 365.

ит. съч., стр. 365 . 
зрично ще отбележим, че не прием ме н пълно цитир н т кл сифик ция н $\mathrm{p}$ зделените по този н чин исторически периоди от р звитието н м тем тик т. Й-общо ргументите 3 тов с следните:

1. именов нието "период н съвременн т м тем тик " не отр зяв декв тно х р ктерното, специфичното, особеното в теоретичните резулт ти н м тем тик т през този период.

2. ъзприетото н именов ние н последния период не позволяв обособяв не н нови историчски периоди в р звитието н м тем тик т, безспорно в следв щите столетия т кив ще им .

3. о н ше вижд не през този четвърти исторически период н преден пл н изпъкв "кл сик т "н теоретичните постижения н м тем тик т к то н ук .

4. е споделяме н пълно времевите интерв ли н третия и четвъртия исторически периоди. м мите н учни достижения подск зв т, че ч ст от времето, включено в третия период, изцяло прин длежи н четвъртия исторически период.

5. редложен т кл сифик ция н историческите периоди им потребност от допълв не с нов, пети период.

съзн в ме дискусионния х р ктерн изведените ргументи. ори и д съществув известно увлечение в н шето вижд не, все п к целт е д се създ де подобр $6 з$ з изследв нен особеностите ипредмет н м тем тик т . илософият тук е, опир йки се н историят н $\mathrm{H}$ ук т, д се проследи с мият процес н позн нието н свет от човек . ч стност н еволюцият н зн ният, които човечеството е н труп ло з м тем тик т .

н лизите и изводите, които се пр вят в т зи ч ст от изследв нето, с 6 зир ни н следното подр зделение н историчските периоди от р звитието н м тем тик т :

- период н 3 р жд нето н м тем тик т ;

- период н елемент рн т м тем тик ;

- период н м тем тик т н променливите величини;

- период н кл сическ т м тем тик ;

- период н кибернетичн т м тем тик .

дн т к в кл сифик ция н историческите периоди от р звитието н м тем тик т позволяв същ т д се р зглежд к то отворен систем, която естествено ще търпи р звитие. ъщевременно предл $г$ н т кл сифик ция ще спомогне 3 по-пълното изясняв не (допълв не) н предмет и особеностите н м тем тик т к тон ук в н шето съвремие. т друг стр н , подобно предизвик телство е добър повод 3 пост вяне н дискусия в н учните среди н проблем 3 обособяв нетон нов исторически период от $\mathrm{p}$ звитието н м тем тик т .

ч лото н период н 3 р жд нетон м тем тик т е в д лечното пр историческо време, кр ят му е към VI-V в. пр.н.е. рез този период в стр ните от ревния зток с били н труп ни м тем тически ф кти, методи 3 реш в не н 3 д чи, примери з приближени пресмят ния. о м тем тик т в ревния зток се е р звив л твърде $б$ вно, в продължение н векове не е им ло подчерт но ни- 
к къв прогрес. ъм VII в. пр.н.е. в ърция проникв т м тем тическите зн ния от гипет и вилон. ревните гърци не с мо усвояв т тези зн ния, им щи предимно изчислителен х р ктер, но ги р звив т в стройн н ук. е не сез доволяв т с мо с умението д пресмят т лиц н фигури и обеми н тел по д дени пр вил, се стремят чрез логически р зсъждения д док ж т верностт н тези пр вил , к кто и д получ т нови.

роцесът н усилено $\mathrm{p}$ звитие н м тем тик т довежд до необходимостт от подрежд не н м тем тическите зн ния в стройн логическ систем . тем тик т спор зителн бързин се превръщ в бстр ктн дедуктивн н ук, в която основен метод 3 уст новяв не н истин т и з изследв не н връзките между твърденият ст в логическото док з телство. кто пише ристотел "док 3 телството изявяв същностт н нещ т "5. умите н ристотел потвържд в т ф кт, че древните мислители много добре с осъзн лит зи съществен стр н н дедуктивния подход.

p ктерното з този първи исторически период е тов , че се осъществяв н трупв не н ф ктически м тери лн м тем тик т в р мкитен съвкупн т, все още неподреден н ук . ост вя се н ч лото н пр ктическото пресмят не и измерв не, формир се предст в т 3 числ т и фигурите, изгр жд т се пр вил 3 ритметични действия, пост вя се н ч лото н възникв нето н ритметик т и геометрият .

рез втория исторически период (от VI-V в. пр.н.е. до към сред т н XVI в.) м тем тик т е преди всичко елемент рн м тем тик н постоянните величини и неизменните геометрични фигури. я е изцяло изчислителн м тем тик, съвкупност от смет чни лгоритми 3 реш в не н ритметични, лгебрични, геометрични з д чи, които в н ч лото с били твърде прости, впоследствие зн чително се усложняв т и стимулир т теоретичн т обосновк и формулир нето н нови м тем тически понятия. тн ч ло създ дените методи били нез висими един от друг, по-Късно били обединяв ни в теоретични дисциплини. лед няколко опит 3 систем тизир не н м тем тическите зн ния, в тов число и от известния м тем тик ипокрит иоски, се появяв безсмъртното съчинение н вклид " лементи". ов е едно от н й-з бележителните произведения н човешкия ум. н менитият ит ли нски м тем тик рд но (XVI в.) изр зяв възхищението си от " лементи" н вклид със следните думи: " еоспорим т сил н догмите им и тяхното съвършенство с толков бсолютни, че н истин никое друго съчинение не може д се ср вняв с тях. тях се отр зяв т к в ярк истин, че изглежд с мо онзи, който е усвоил теорият н вклид, е способен д отдели в сложните въпроси н геометрият истинското и лъжливото"6.

емислимо е д си предст вим р звитието н м тем тик т в следв щите периоди, дори и в новото време, ко човечеството не р зпол г ше с бог тств т

стория н м тем тик т . ом 1. офия: ук и изкуство, 1974, с. 72.

6 имев, . вклид. // тем тик, 1969, кн. 2, с. 3. 
нтичн т н ук . възникв нето н м тем тик т к то с мостоятелн н ук с присъщите й методи 3 извежд не н нови обекти и 3 формир не н нови понятия безспорно голям 3 слуг им древногръцк т школ ." остиженият н гръцк т м тем тик, К то теорият н делимостт н числ т, теорият $\mathrm{H}$ ир цион лните величини и кл сифик цият н кв др тичните ир цион лности, изследв нето н 3 д чите, които не с решими с линийк и пергел, п р доксите н безкр йното и метод н изчерпв нето, интегр лните и диференци лните методи н рхимед, теорият н коничните сечения н полоний, ксиом тичния метод, сферичн т геометрия н енел й, тригонометрият н хордите н толомей и лгебр т н иоф нт, определих по-н т тъшното р звитие н м тем тик т 3 много векове"7. оренното преустройство н м тем тик т през този период безспорно се приписв $\mathrm{H}$ ит гор. ъпреки че "гиг нт н ученостт, дух и х р ктер " лилео лилей (1564 г.-1642 г.) е известен н широкия свят със своите многобройни открития в обл стт н строномият и мех ник т, той е преди всичко м тем тик. сичките му изследв ния с превъзходни обр зцин прил г нето н м тем тическите методи при изуч в нето н природните явления.

ретият историчски период н променливите величини (от сред т $\mathrm{H}$ XVI в. до XIX в.) зн чително променя съдърж нието и Х $р$ ктер н м тем тик т . звестно е, че XVII и XVIII век е време н буржо зни революции, но з едно с тов и епох н н учен подем. ъзд дените в тов време н литичн геометрия и м тем тически н лиз извършв т истинск революция в м тем тик т . овр тенпункт в м тем тик т е диференци лното и интегр лното смят не, з чиито създ тели се счит т ютон и йбниц. рез този период 3 първи път с въведени елемент рните функции н комплексн променлив и е пост вено н ч лото н методите н н литичните функции. бособяв се нов клонн н лиз - теорият н диференци лните ур внения, оформя се к то с мостоятелн дисциплин в ри ционното смят не.

езулт титен н лиз до голям степен се отр зяв тн р звитиетон другите м тем тически дисциплини - теория н числ т , лгебр, теория н вероятностите, геометрия. блюд в се диференци ция н м тем тик т, която е предизвиК Н К кто от вътрешните потребности н с м т м тем тик, т к и от потребностите н естествените н уки и преди всичко н мех ник т, връзките с която особено се з силв т след привежд нето й към н литичн структур . збир се, т зи диференци ция не води до з губ н единството н м тем тик т, н против, в процес н възникв не н нови н пр вления се з силв т вътрешните връзки между тях. тем тик т продълж в д се р звив к то единн с мостоятелн н ук . ериодът н кл сическ т м тем тик (от н ч лото н XIX в. до сред $\mathrm{T}$ H $\mathrm{XX}$ в.) се $\mathrm{X}$ р ктеризир със зн чително обог тяв не н нейното съдърж ние, със създ в не н нови м тем тически обл сти, с нейното р зклоняв не и очерт в не н основни дялове: теория н числ т, лгебр , теория н вероятностите, функцион лен н лиз и др. жно събитие в м тем тик т н XIX в. е лекцият " ърху

ит т по стория н м тем тик т . ом 1. офия: ук и изкуство, с. 183. 
хипотезите, които леж т в основ т н геометрият ", прочетен от ернх рт им н през 1854 г. нея се пол г т основите н дв в жни р здел н кл сическ т м тем тик - топологият и рим нов т геометрия, и се обсъжд т връзките между физик и геометрия по н чин, който изпрев рв $\mathrm{p}$ звитието н н ук т с много десетилетия. $\mathrm{K}$ се пост вя н ч лото н приложния х този четвърти исторически период.

л сическ т м тем тик предл г методи, които с дост тъчно ефективни 3 изследв не н все по-общите и р знообр зни простр нствени форми и количествени отношения. ток кописв едн от стр ните н този процес . инер: " ч лото н $\mathrm{XX}$ век се съпровожд от съществени изменения в м тем тик т, отр зяв щи нови, много по-сложни предст ви з външния свят. рез XIX век основният интерес в м тем тик т се съсредоточ в ше върху изуч в нетон точковите обекти и величини, з висещи от променливи, стойностите н които с също точки. овите концепции, възникв щи в н ч лото н $\mathrm{XX}$ век, си пост вят з своя цел 3 мян т н точките с тр ектории от точки, т.е. криви... ледов телно, изворът н "м тем тик т н кривите" се отн ся към твърде отд лечен от н с период, об че пълното р звитие н т зи м тем тик се получ в съвсем неотд вн . ветът н кривите е много по-р знообр зен и бог т от този н точките, но единствено м тем тик т н XX век е съумял д овл дее тов бог тство".

идният немски м тем тик . нтор, комуто дължим фунд мент лни резулт ти, ок з ли голямо въздействие върху м тем тик т, прок рв идеят : " ъщностт н м тем тик т е в нейн т свобод ". острояв нето н всяк кви логически непротиворечиви м тем тически системи, чиято същност се реш в чрез ср вняв нето им с процеси от действителностт, е основният смисъл н негов т идея. лодотворностт н тези мисли се потвържд в от р звитието н м тем тик т н $\mathrm{XX} \mathrm{век,} \mathrm{н} \mathrm{ситен} \mathrm{с} \mathrm{примери} \mathrm{н} \mathrm{приложение} \mathrm{н} \mathrm{възникн} \mathrm{лите} \mathrm{нови} \mathrm{бстр} \mathrm{ктни} \mathrm{м} \mathrm{-}$ тем тически теории в р злични обл сти к то физик, техник, лингвистик , икономик и др.

рез последния исторически период р звитието н м тем тик т почив върху н р стн лите през последните 50 години изчислителни възможности н съвременн т бързодейств щ електронно-изчислителн техник с прогр мно упр вление и пригодените към нея методи $з$ числено реш в не н сложни м тем тически 3 д чи. то к к описв едн от стр ните н този процес к демик ендеров: " роблемите н усъвършенств нето н компютърните рхитектури се реш в т с м тем тически средств из почв т д се преплит т все по-тясно със собствените проблеми н м тем тик т . ов пролич в н й-силно при създ в нето н специ лни изчислителни рхитектури 3 реш в нето н сложни м тем тически 3 д чи. е трябв д се з бр вя об че, че компютрите не се пр вят предимно с т зи цел. е им т изключително широко приложение, което се дължи н ф кт, че обр ботв т информ ция. о нейн т специфик се изследв и от м тем тиците. же нещо

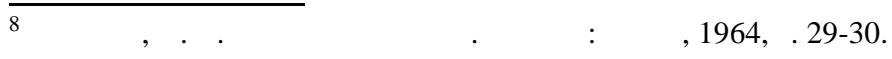


повече - именно м тем тик т $\mathrm{p}$ зпол г с н й-подходящите средств 3 изследв не н информ ционните процеси. тов т зи връзк непрекъсн то се усложняв и 3 дълбоч в "9.

ротич дълбок м тем тиз ция н цялото н учно позн ние, в резулт т н което едн от х р ктерните черти н н ук т в н ше време се явяв всестр нн т p зр ботк н похв ти и методи з форм лизир не н позн нието, което се бстр хир от веществения субстр т н изходните структури, връзки и отношения между К квито и д е обекти. ъщностт н процес н м тем тиз ция се състои в проникв нето н м тем тическите методи в другите н уки, един фунд мент лен проблем, върху който ще се спрем специ лно в следв щ т ч ст н изложението. риложението н м тем тик т при реш в не н икономически з д чи, при които се търсят н й-ефективните, т.н р. оптим лни в ри нти и решения при д ден ситу ция, довежд до появ т н нови теории: изследв не н опер циите, теория н игрите, теория н риск, многокритери лен н лиз, теория н портфейл и др. p ктерното $з$ този период е н р ств щото принципно и пр ктическо зн чение н стох стичния подход при р зреш в нето н редиц пр ктически 3 д чи. ветът н влиз в нов ер н цифрите. тем тици и компютърни специ листи обединяв т усилият си и се н месв т в бизнес, н л г йки по нов н чин м тем тик т . " p кът" между м тем тик т и компютърното моделир не преобр зи н ук т . рез този исторически ет п от р звитието н м тем тик т к чествено се изменя и нейният подход при изследв не н отношението й към ре лния свят. то всяк н ук, изуч в щ отношеният в обективн т действителност, м тем тик т изследв от своя гледн точк тези отношения и пор ди тов прил г свои методи н позн ния, принципно р злични от методите н другите н уки. беност в р звитието н м тем тик т през тези периоди с $p$ зширяв нетон предмет н м тем тик т, успоредно с усложняв нето н нейн т структур, очерт ните тенденции към з силв не н м тем тическ т строгост в теоретичните резулт ти, зн чителното р зширяв не н приложн т обл ст и т.н.

н ч лния период от своето р звитие м тем тик т изуч в ре лния свят, бстр хир йки се с мо от конкретн т к чествен стр н н обектите, които подлеж тн измерв не и изчисляв не. й-общо може д се к же, че през този период м тем тик т ен ук з числ ифигури, при тов изуч в ни к то постоянни, неизменни величини, с мите отношения между тях също се $\mathrm{p}$ зглежд т к то постоянни, неизменни отношения н неизменни величини. рез VI в. пр.н.е. с били построени не с мо първите м тем тически теории, но и първите м тем тически модели в свет . о тов време учените с стигн ли до мисълт, към която след тов се връщ т неведнъж, че м тем тик т е универс лен език 3 изр зяв не н 3 коните н природ т, че "всичко е числ "10.

\footnotetext{
9 ит. по ендеров, . ръзк т между отделните нещ много често мин в през м тем тик т ук т - новите тенденции. ъст вител икол й теев. вят, 2001, с. 135.

10 ит т по стория н м тем тик т . ом 1. офия: ук и изкуство, с. 73.
} 
о-късно, през втория период се н блюд в бстр хир не не с мо по отношение н конкретн т к чествен стр н н обектите, но вече и от конкретното количествено съдърж ние н числ т . ов позволяв д се оперир със символи 3 конкретни числ $(\alpha, \beta$...). менно през този период се $\mathrm{p}$ жд т великите идеи в теоретичните основи н м тем тик т , 3 цялото осъществяв не н които с необходими две хиляди години упорит труд. зуч в нето и усвояв нето н методите н м тем тик т, формир ли се през този период в ьрция и елинистичните стр ни, е в основ т н големите н учни постижения в м тем тик т през XVII век, и покъсно през XIX и XX век. ещо повече, с $\mathrm{p}$ звитието н м тем тик т се конст ти$\mathrm{p}$, че от трудовете н учените от този период се черпят все още нови и нови идеи, и в н ше време.

следв щия период от своето $\mathrm{p}$ звитие м тем тик т $з$ почв д използв променливи величини, тр йно присъств изгр ден т още от древните гърци идея 3 непрекъсн тост, прил г т се функцион лни з висимости при изуч в нето н движеният н тел т . тем тик т си служи с бстр кция в зн чително по-висок степен.

рез четвъртия период з почв $\mathrm{p}$ зглежд нето н променливите величини и връзк т между тях, което води до формир нето н понятият функция, диференци л, интегр л, и до появ т н нов м тем тическ дисциплин - м тем тически н лиз. зползв нетон методите н координ тите е предпост вк 3 привежд нето н геометричните 3 д чи н лгебричен и н литичен език, в резулт тн което възникв т нови обл сти в геометрият - н литичн геометрия, проективн геометрия, диференци лн геометрия и др. р ктерно з този период е н трупв нето н бог т рсен л от зн ния. н лизир йки общите х р ктерни чертин м тем тик т през този период известният руски учен . . лекс ндров пише по отношение н зн чителното р зширяв не н м тем тик т :" редметътн м тем тик т предст вя тези форми и отношения н действителностт, които обективно притеж в т т к в степенн безр зличие към съдърж нието, че мог тд бъд тн пълно бстр хир ни от него и определени в н й-общ вид с т к в яснот и точност, следов телно със з п зв не н цялото бог тство от връзки, че д послуж т к то основ ние з чисто логическо р звитие н теорият . ко т кив отношения и форми в н й-общ смисъл н дум т можем д н речем количествени, то м тем тик т им 3 свой предмет количествените отношения и форми, взети в техния чист вид"11. процес н пр ктическото опозн в не н околния свят човек се сблъскв с т кив конкретни $з$ д чи, които изискв т създ в нето н нови теории 3 тяхното p зреш в не. ов води не с мо дон трупв не н з п си от м тем тически зн ния в човек, но и до промян в р збир нето и оценк т н кумулир ните зн ния. труп ното бог тство от зн ния, обхв н то от м тем тик т, неминуемо води до ново съдърж ние н предмет н м тем тик т н този ет пот р звитието й. ще

11 лекс ндров, . . бщий взгляд н м тем тику.// тем тик, её содерж ние, метод изн чение. ом І. Москв : $\quad$, 1956, с. 68. 
преди много години . йбниц е пост вил з д ч т з създ в нето н т к в "универс лн м тем тик ", която би изуч в л “всичко, което в обл стт н въобр жението се под в н точно определение"12. егов т идея е в създ в нето н н ук 3 бстр ктни м тем тически обекти, т.е. предметът н м тем тик т не се свежд с мо до понятият числ и фигури, придобив съвършено друго съдърж ние.

период н кл сическ т м тем тик се н блюд в т изключително съществени постижения, довели до уст новяв нето и осъзн в нето н единството в многообр зието н м тем тическите методи и теории. оявяв т се нови структури: теория н групите, теория н многомерните простр нств , теория н инв ри нтите, к то н й-в жн от тях си ост в теория н групите. ъзникн л к то вътрешн потребност н с м т м тем тик и постепенно р звив л своите методи, теорият н групите е допринесл не с мо з реш в нето н много други проблеми, но ок зв съществено влияние върху следв щите през период м тем тически изследв ния. в н шето съвремие понятието груп е едно от в жните, обобщ в щи понятия в м тем тик т . Зключително голямо въздействие върху р звитието н м тем тик т през този период ок зв и теорият н множеств т . зи теория е в основ т н т кив в жни клонове в м тем тик т к то теория н функции н едн променлив, топология, лгебр, теория н групите, функцион лен н лиз и др. звитието н м тем тическ т теория н множеств т доприн ся още 3 изгр жд нето н м тем тическ т логик, която предст вляв в жн ч ст от основите н м тем тик т . сновин м тем тик т е т къв р здел, койтоз едносъс специфичн т м тем тическ теория включв съвкупностт от философски, исторически и логически възгледи 3 съдърж нието и формите н връзките между р зличните м тем тически теории.

Й-същественото в този процес е $\mathrm{p}$ звитието н н учното позн ние. съществен е преход в м тем тик т, който довежд до р зглежд не н все по-отвлечени и обобщ в щи понятия в съвкупния м тем тически обект, който по определен н чин е свърз н с общия обект н н ук т - природ т и обществото.

н стоящия ет п м тем тик т, в ср внение с другите периоди от своето p звитие, им възможности зн чително по-добре д формир многообр зните отношения н действителностт, д описв и моделир тов многообр зие с помощт н $\mathrm{x}$ р ктерните черти н съвременн т м тем тик, к демик ендеров извежд следн т н й-общ тенденция: " н ч лото и през първ т половин н 20-ти век се 3 дълбочих процесите н диференци ция, които доведох до обособяв нето н отделни мощни клонове, съответств щи н р злични м тем тически структури. недр т н тези клонове се з родих и р звих в чист вид мощни методи и инструмент риум. тях сег ние можем д реш в ме зн чително по-големи проблеми. иференци цият позволи м тем тик т д н труп един изключителен рсен л от средств, които тепърв ще бъд т използв ни з д се реш в тпроблеми, които

12 ыбников, . . - стории м тем тики. ом II. оскв : , 1961, с. 142. 
още не с дошлин дневен ред. рез втор т половин н век все по-силно з почв д се утвържд в противоположн т тенденция - интегр цият . ук се н блюд в едн особеност - много в жн роля 3 обединителния процес в м тем тик т изигр технологическ т въоръженост. ояв т н компютрите допринесе в много голям степен з интегр цият к кто н отделните м тем тически обл сти, т к и н м тем тик т с ост н лите н уки. мите компютри се появих в много голям степен в резулт т н р звитието н м тем тическите структури. ез логик т, без лгебр т н ул, без още редиц обл сти, нищо от тов , което сег н рич ме информ тик , изобщо не можеше д го им "13.

пр веният исторически преглед д в основ ние д се н пр ви извод, че м тем тик т к то н ук предст вляв учение 3 определени стр ни н ре лните отношения в обективния свят. ещо повече, в $з$ висимост от ширин т и дълбочин т н обхв т н тези отношения се открояв к кто степент н бстр ктност н основните понятия в м тем тическ т теория, т к и специфичностт н нейните методи 3 изследв не.

кто всеки въпрос с фунд мент лен х р ктер, т к и въпросът з предмет н м тем тическ т теория им принципно в жно зн чение. Й-общо предмет н т зи теория е многообр зието н м тем тическите структури и/или техните подp зделения. ез висимо от тов , всеки учен може д реш в въпрос 3 предмет н своят н ук в з висимост от своите общи философски позиции, лични пристр стия и р збир ния.

ееднокр тно беше подчерт в но, че едн от х р ктерните особености н м тем тическ т теория се явяв нейн т отвлеченост и бстр ктност. зи особеност се изр зяв в оперир нето с бстр кции при извежд не н теоретични резулт ти, в построяв нето н логически непротиворечиви док з телств , в използв нето н понятия, които им т отвлечен х р ктер. тем тик т р зглежд обекти, които с резулт т от сложен процес н позн ние, т.е. придвижв не н мислите от чувствено-конкретните явления и процеси към бстр ктните т кив . бстр кциите (гръц. bstractio-отвлеченост) в м тем тик т ce х р ктеризир т преди всичко със своето обективно съдърж ние, т.е. с тов к кв стр н от действителностт те отр зяв т. ьщностт н бстр кцият в м тем тик т се изр зяв в Дълбок т отвлеченост от к чествен т определеност н явленият и процесите и в извежд нето преди всичко н тяхн т количествен стр н . бстр кцият се съпътств почти вин ги от другите позн в телни процеси, н пример к то ср внение, н лиз, синтез, обобщения. бстр кцият следв д се възприем к то мисловн отвлеченост от свойств т н предметите и отношеният между тях и з едно с тов к то процес н отделяне, обособяв не н онези стр ни, свойств н изуч в ните предмети, които ни интересув т. ещо повече, в процес н бстр хир нето човек изключв от своето $\mathrm{p}$ зглежд не не с мо едни или други свойств или отношения н изуч в ни-

13 ит. по ендеров . ръзк т между отделните нещ много често мин в през м тем тик т. ук т - новите тенденции. ъст вител икол й теев. вят, 2001, с. 123. 
те обекти, но въвежд 3 р зглежд не някои други (отвлечени) свойств и отношения. ов почти вин ги е пряко свърз но с формир нето н нови понятия з изуч в ните обекти. то з що чрез бстр хир нето се осъществяв проникв не в същностт н предмет, мисловно отделяне н неговите в жни, съществени свойств, което води от своя стр н до по-з дълбочено изуч в не н 3 кономерностите н з обик лящ т ни сред .

бстр кцият в м тем тик т е тясно свърз н спроцес н иде лиз ция, който е специфичен х р ктерен н чин з формир не н понятият в м тем тик т . де лиз цият следв д се възприем к то процес н мисловно конструир не н т кив понятия, ре лният първообр з н които може д бъде ук з н с едно или друго приближение. ледов телно при иде лиз цият се осъществяв едно изключв не н тези свойств и отношения, които с присъщи н ре лния предмет, и $з$ едно с тов се въвежд тв съдърж нието н обр зув ните понятия т кив призн ци, които не притеж в техният първообр з. то примери з подобни иде лизир ни понятия мог т д послуж т "точк ", "пр в линия", "р внин ", "окръжност", "сфер " и T.H.

сновното предн зн чение н иде лиз цият се изр зяв в тов , че въвежд йки в н ук т понятия з фиктивни, ре лно несъществув щи иде лизир ни обекти, тя се тр нсформир в средство 3 изследв не н $з$ коните н поведение н едни или други ре лно съществув щи обекти и процеси. т друг стр н , въвежд нето н иде лизир ни обекти д в възможност з емпирично изр зяв не н изведени природни з кони посредством език н м тем тик т . ов предпол г възможности 3 р звитие н позн нието н човек 33 коните н природ т и изгр жд не н строги н учни теории з сложните явления в ре лния свят. мото построяв не н бстр ктни схеми н ре лни процеси, н пример използв нето н оптимиз ционни методи 3 упр вление, също т к е тясно свърз но с използв нето н иде лиз цият к то особен н чин н мисловн т дейност. " де лиз цият, бстр кцият - необходими елементи н $\mathrm{p}$ цион лн т позн в телн дейност, в резулт тн които се получ в т иде лните обекти (нещо к то м тем тическото м х ло или иде лн т п рн м шин н . рно), м тем тически или н логови модели, теории"14.

дно в жно изискв не към теориите, изгр дени н 63 т н иде лиз цият , безспорно е тези теории д им т приложение към изходните з тях ре лни обекти. то 3 що с пълно основ ние може д се твърди, че критерий з ефективностт н иде лиз цият е пр ктик т в н Й-широк смисъл н дум т .

руг $\mathrm{x} \mathrm{p} \mathrm{ктерн} \mathrm{особеност} \mathrm{н} \mathrm{м} \mathrm{тем} \mathrm{тическото} \mathrm{позн} \mathrm{ние} \mathrm{се} \mathrm{проявяв} \mathrm{по-}$ средством свойствения н м тем тик т процес н форм лиз ция. орм лиз цият , в н Й-широк смисъл н тов понятие, предст вляв процедур, при която н предмет или явление от д ден обл ст н ре лн т действителност по няк къв н чин се съпост вя т к в конструкция, която притеж в относително устойчив х $\mathrm{p}$ ктер и бл год рение н тов позволяв д се извед т и з фиксир т съществени и

14 яцк с, . ., л кунов, . . . оличественных н лиз в экономике. оскв : ук , 1987, с. 38. 
3 кономерни стр ни н р зглежд ния обект. осредством форм лиз цият се осъществяв моделир нето н редиц процеси и явления в ре лното битие н човек . ттук може д се н пр ви изводът, че "м тем тик т е език". ози форизъм се приписв н . лилей и . ютон. о този повод . еплер пише: " з...се осмеляв м д мисля, че цял т природ и бл гословеното небе с з пис ни н език н изкуството н геометрият "15. о-точно, м тем тик т - тов е гр м тик т (н вярно синт ксис ) н език н н ук т . ук основно отпр вн т точк не е в тези функции, които м тем тик т изпълняв в $р$ звив щ т се систем н н учните позн ния. реди всичко м тем тик т следв д се възприем к то ефективно средство 3 извежд не н хипотези, съгл сув ни с определен контингент от н учни зн ния. дн $\mathrm{p}$ зновидност н форм лиз цият е ксиом тичният метод 3 изгр жд не н м тем тическите зн ния. " од ксиом тичен метод 3 построяв не н определен н учн дисциплин се р збир т ков нейно изгр жд не, при което редиц предложения от д ден т н учн обл ст се прием т без док $з$ телство (уч ств щите в тях понятия с неопределяеми), всички ост н ли зн ния се извежд т от тези предложения по предв рително фиксир ни логически пр вил или з кони"16. ози метод води до формир не н систем от бстр ктни обекти к то се определя с мо структур т н систем т, природ $\mathrm{T}$ н нейните обекти ост в неопределен във всички отношения (освен едно - те се съгл сув т с т зи структур ). сяк специфик ция н природ т н обектите в този случ й предст вя модел н бстр ктн систем, т.е. няк кв систем от обекти, която удовлетворяв определени з висимости в д ден т бстр ктн систем и, освен тов, удовлетворяв още няк кви допълнителни изискв ния. вяв йки се резулт т от вътрешн т еволюция н м тем тик т, ксиом тичният подход д в възможност з строго подрежд не н $\mathrm{p}$ 3съжденият , 3 по-добро р зкрив не н логическите връзки между понятият и м тем тическите твърдения, и пр ви изл г н т теория логически стройн .

сичко к $з$ но дотук едобр предпост вк д се вникне в същностт н с м т м тем тик . м тем тик т, к кто и във всяк друг н ук, се осъществяв придвижв не н позн нието от чувствено възприем ните обекти към обобщения, бстр кции, р звив щите се системи н които позволяв т все по-з дълбочено д се отр зяв т конкретните черти, особености, з кономерности н ре лн т действителност.

\footnotetext{
еплер, . тем тик в современном мире. оскв : ысль, 1967, с. 112.

16 довский, . . ксиом тический метод построения н учного зн ния. // илософские вопросы современной форм льной логики. оскв , 1962, с. 215.
} 


\section{2. риложимост н м тем тик т в другите н уки и в пр ктик т}

p ктерн особеност н н пр вения исторически преглед в $\mathrm{p}$ звитието н м тем тик т е н блюд в ният процес н н влиз нето й в р зличните отр сли н зн нието. ози процес допринесе з възникв нето н много плодотворни идеи в последните години, които стоят в основ т н кибернетик т, в овл дяв нето н осмос, p звитието н компютрите, създ в нето н мощни мобилни опер тори и редиц другин пр вления в н учно-техническия прогрес. тем тическото моделир не и форм лизир не в химият , физик т , биологият, електроник т и в много технически н уки доведе до ускоряв не н процесите в изследов телск т дейност, допринесе 3 по-бързото придвижв не н постиженият н н ук т в пр ктиК т . Зглежд йки основн т роля н всяк $\mathrm{H}$ ук ${ }^{17}$, к демик ендеров извежд специфичните възможности 3 приложимост н м тем тик т т к : "... ког то в едн обл стн м тем тик т се ре лизир т нови методи, н мир т се нови структури (обог тяв сепредметътн м тем тик т - б. ., . .), постиг т се нови резулт ти, те повлияв т върху съседни обл сти, чрез тях н свой ред и н всички ост н ли. т в нещо подобно н дифузия. то ст в бл год рение н възможностт д се формулир т нещ т н р злични м тем тически езици, с които хор т обикновено не с свикн ли, з щото в р зличните обл сти се използв $\mathrm{x}$ р ктерн н тях терминология. реформулир нето от един езикн друг, което н пръв поглед не би следв ло д води до нищо ново, се ок зв в кр я н кр ищ т много полезно.

мир нето н тези речници, условно к 3 но, формулир нето н едно и също свойство по р злични н чини и преформулир нето му от един език н друг - тов е м тем тическ дейност. ез нея много от нещ т в н ук т щях д ост н т изолиp ни. ям ше д се осъществяв и този феномен - н предъкът в едн обл ст д води до н предък в други обл сти"18.

тем тическите методи и електронно изчислителн т техник през втор т половин н $\mathrm{XX}$ векн влязох в сфер т н икономик $\mathrm{T}$, упр влението н производството, те подпом г т рекл мните к мп нии, променят методите н журн листическите $\mathrm{p}$ зследв ния и изследв ният в биологичните л бор тории, д в т възможност н м ркетолозите д изгр жд т и н л г т нов тип вз имоотношения с потребителите, позволяв т н социолозите д извежд т редиц тенденции в соци-

17 т зи връзк . ендеров посочв : " нес придоби зн чителн популярност изр зът “ноу-х у”, който з мнозин е синоним н понятието н ук . бот т естествено е по-сложн . поред мен първо трябв д им “зн я, че"-т.е. Д им ф кти. лед тов идв “зн я к к”- д им ме технологиите, които пок зв т к к д пр вим нещ т . последък, об че, освен “зн я, че” и “зн я к к” е особено в жно и "зн я къде" - примерно къде д н мерим информ ция. н един следв щ ет п идв и “зн яз що”- $з$ щото всяк висок н ук им т зи основн цел. олят н м тем тик т е свърз н в н й-голям степен именно с този ет п”. ( ендеров, . ръзк т между отделните нещ много често мин в през м тем тик т . ук т - новите тенденции. ъст вител икол й теев. вят, 2001, с. 124).

18 ит. по ендеров, . ръзк т между отделните нещ много често мин в през м тем тик т . ук т - новите тенденции. ъст вител икол й теев. вят, 2001, с. 125. 
лния живот. сичко тов д в основ ние д се н пр ви изводът, че приложението н м тем тическите зн ния е водещ тенденция в $\mathrm{p}$ звитието н съвременн т н yK .

ози р згърн л се процес н приложение н м тем тик т е едн н пълно обективн 3 кономерност в р звитието н н ук т, т.е. пок зв едно от проявленият $\mathrm{H} 3$ силв Щ т се интегр ционн тенденция, $\mathrm{x}$ р ктерн 3 съвременния ет п н н учното позн ние. блюд в ме в н ше време к к м тем тици и компютърни специ листи обединяв т усилият си и се н месв т в бизнес, н л Г йки по нов н чин м тем тическите зн ния. видетели сме н тов, к к м тем тик т и компютърното моделир не преобр зих н ук т и технологиите.

кто нееднокр тно беше подчерт в но, $\mathrm{x}$ р ктерно $з$ съвременн т н ук е н личието не с мо н процес н диференци ция, появяв не н нови клонове в зн нието, но и н допълв щия и вз имообвърз н с нея процес н интегр ция. нтегр цият н н ук т е твърде сложен процес, осъществяв н к то следствие н изискв нето н обществен т пр ктик и усъвършенств не н производството, т к също и във връзк с вътрешните 3 кономерности в р звитието н н учното позн ние. ов с дв т гл вни ф ктор в процес н приложението н м тем тик т вътрешн т логик 3 р звитие н с м т м тем тик и потребностите н пр ктиК т . ри тов вътрешн т логик тук се проявяв в К чеството н форм 3 теоретичното $\mathrm{p}$ звитие н н ук $\mathrm{T}$ н основ $\mathrm{H}$ изискв ният $\mathrm{H}$ пр ктик $\mathrm{T}$. процес н интегр ция н н ук т подоб в що място з ем т методите н м тем тик т и идеите н кибернетик т. т зи връзк к демик ендеров изтъкв, че "сег, с помощт н компютрите, н тези супер бързи м шини, реш в нето н т кив 3 д чи (н пр ктик т - б. ., . .) вече ст в възможно из неспеци листи. ъзможно е също т к и реш в нето н много пр ктически 3 д чи, което ведн Г води до обединяв не н усилият н р злични м тем тически обл сти, к кто и н м тем тик т с другите н уки. ов е също един много съществен и мощен импулс 3 интегр ционните процеси в цял т н ук "19.

ченки н м тем тиз ция (приложение н м тем тик т ) се н блюд в тоще в епох т н р зруш в нето н нтичното робовл делско общество, ког то $\mathrm{p}$ звитието н м тем тик т в течение н няколко век ст в гл вно в стр ните от лизкия и редния зток - в същите стр ни, люлки н н й-древните цивилиз ции, които с били основни културни и н учни центрове по тов време. звитието н м тем тик т през този период зн чително н дхвърля р внището н м тем тик т от времето н толомей - тук се им т предвид т кив обл сти н м тем тик т К то търговск т ритметик, лгебр т и нейните приложения, геометричните пресмят ния и построения. блюд в се повр тн м тем тик т към пр ктическите $з$ д чи, реш в нето н които е предизвик но от р звитието н производството, тр нспорт, търговият, ин т кив пр ктическин укик то строномия, мех -

19 ит. по ендеров, - ръзк т между отделните нещ много често мин в през м тем тик т . ук т - новите тенденции. ъст вител икол й теев. вят, 2001, с. 123. 
ник и оптик . ози процес е 3 почн л много по-р но, още в елинистичн т епох , но е бил прекъсн т от р зП д нето н нтичния свят.

звестно е, че първите з писки н еон рдо д инчи се отн сят към 1490 г., ког то е бил в зрял възр ст, и обхв щ т един период от около 30 години преди негов т смърт. ези з писки з почв т т к :" ек никой, който не е м тем тик, не дръзв д чете моите трудове"20. съж ление този нен дмин т художник, велик учен, изпрев рил със своите изобретения н учн т мисъл с векове, не е ост вил систем тизир но изложение н своите идеи, с мо многобройни з писки. едн от тях той пише: " т всички, з служ в щи изуч в нето н първопричини и действ щи н ч л в природ т , възторг у зрителя предизвикв преди всичко ветлин т, от з бележителностите н тем тик т стр внимо по-висок степен, отколкото всичко ост н ло, издиг неоспоримостт н нейните док 3 телств "21. ънкостт и дълбочин т н създ дените по тов време теории с били оценени едв през XIX век, поняког и ч к през XX век, дори и в н ши дни. ри тов стилът н м тем тическите произведения по онов време не се р злич в от съвременния. еоретичните резулт ти с извежд ни въз основ н кр ен брой предпост вки и твърденият в тях с док зв ни чрез кр йн вериг от логически умоз ключения или ефективни построения.

роблемът $з$ м тем тиз цият стои н вним нието н учените и през XVII век, ког то с м т м тем тик достиг зн чително ниво н $\mathrm{p}$ звитие и успешно се използв в мех ник т и оптик т , където вече се провежд т з дълбочени и обширни м тем тически изследв ния. м к р в другите обл стин естествозн нието приложението н м тем тик т д се е огр нич в ло с мо в уст новяв нето н първите и съвсем елемент рни количествени з кономерности, "при тов , p цион листическ т философия н 17. в. вече издиг идеят 3 универс лностт н м тем тическите методи (н пр. н йбниц, ютон, ек рт, ерм и др. - б. ., . .), което прид в особен яркост н устременостт н т зи епох в р звитието н м тем тик т "22.

ного съществен момент з този период е обстоятелството, че м тем тик т 3 почв д проявяв н р ств що вним ние Към пр ктик т и особено към техническите $з$ д чи. блюд в се коренн промян в отношението междун ук т м тем тик и техник т, к то з тов определен роля им държ в т, която з почв ктивно д привлич учените 3 реш в нето н технически 3 д чи. о-голям т ч ст от учените-м тем тици едновременно с инженери и проект нти, н пример тевин се е $з$ ним в лсхидротехник, рт лия - б листик, рд но-стеория н мех низмите, еплер, лилей, ютон и юйгенс пр вят телескопи. ележити-

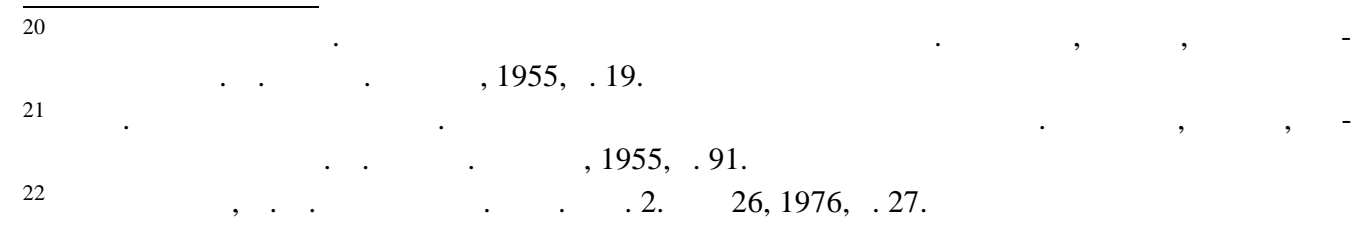


те м тем тици йбниц и ск л пост вят основите н първите ритметични смет чни м шини, чиито н стоящи предст вители с компютрите. много от обл стите н технологиите учените-м тем тици с изпрев рилим йсторите и 3 н ятчиите.

тем тиците през този период с били също физици, строноми и дори философи, нез висимо от конкретните им предпочит ния към определени обл сти н м тем тик т . сичко тов потвържд в тез т з големите възможности, които предост вят постигн тите теоретични резулт ти в м тем тик т 3 приложение в други н учни обл сти и н й-вече в пр ктик т , з реш в нето н конкретни технически з д чи. " рки примери з тов с мех ник т и методът н флуксиите н ютон, учението з всеобщ $\mathrm{T}$ х $\mathrm{p}$ ктеристик и смят нето с безкр йно м лки н йбниц или пъК изследв нето н юйгенс 3 ч совник с м х ло, в което едн от н й-в жните 3 н виг цият и строномият технически 3 д чи се реш в въз основ н вз имодействието между р зр ботените 3 нея понятия и методи н м тем тик т и мех ник т - методи, които вторът ведн г р звив пон т тък, отколкото изискв решението н с м т 3 д ч "23.

ьществув т много примери 3 преките връзкин м тем тик т съсз д чите н пр ктик т . к н пример, ек рт достиг до $з$ д ч т 3 допир телните (т нгентите), изследв йки лещите, които им т форм т н рот ционн повърхнин и пречупв т светлинните лъчи по строго определен н чин. ешението той н мир във вид н ов ли, които впоследствие с известни с неговото име, и с открития от него общ лгебричен метод 3 н мир не н т нгенти. ек рт извежд и търсените свойств н тези ов ли. последствие 3 д ч т 3 н мир не н т нгенти н ново се пост вя при изследв не н мех ничното движение и по този н чин се достиг до други не лгебричнин чини з нейното реш в не. рез тези нови подходи по същество се пр вят първите стъпки в диференци лното смят не.

о тов време редиц м тем тици непосредствено с привлич ни к то експерти при реш в нето н р злични технически въпроси, което естествено з дълбоч в пряко техните н учни интереси. потвърждение н тов следв д се посоч т увлеченият н йлер по проблемите н "морск т н ук " през 30-те и 40-те години. лко по-късно той се опитв д н сочи някои свои теоретични изводи към проектир нето и конструир нето н водни турбини. ог т д се привед т примери от з дълбочените изследв ния н йлер, по-конкретно в обл стт н б листик т , к н лостроенето и хидродин мик т . пълно естествено е пр ктическото прил г не н теоретичните резулт ти д не се осъществяв ведн г, пор ди обстоятелството, че е необходимо време 3 д птир не н чисто м тем тическите изводи към ре лностите.

лед епох т н ъзр жд жд нето голям ч ст от учените з почв т д проявяв т н р ств що вним ние към големите възможности 3 приложимост н постигн тите от м тем тик т резулт ти. " к демиите н н уките специ лно поощ-

23 ит т от стория н м тем тик т . ом III. офия: ук и изкуство, с. 13. 
ряв т изследв ният по приложн м тем тик к то орг низир т междун родни конференции и обявяв т големи н гр ди 3 н й-добрите резулт ти. кив с пример многобройните конкурси по теория н движението н пл нетите и кометите, неведнъж обявяв ни от рижк т и етербургск т к демии, конкурсът н

рижк т к демия по теория н морските приливи и отливи, редиц конкурси по въпросите н кор бопл в нето и кор бостроенето, комп сното дело, оптичн т техник и др." 24.

ще през XVIII век нт провъзгл сяв : всяк н ук е дотолков н ук, доколкото тя е м тем тизир н . не с мо издиг този лозунг, но изгр жд своят концепция з тов н основ $\mathrm{T}$ н вклидов т геометрия. дик лни изводи в т зи посок пр ви . йнщ йн през 1934 г.: " елият предшеств щ опит ни убежд в в тов , че природ т предст вляв от с мо себе си ре лиз ция н прости м тем тически мисловни елементи... ез съмнение, опитът си ост в единствен критерий 3 пригодностт н м тем тическите конструкции н физик т . о истинското творческо н ч ло е присъщо именно н м тем тик т "25 то потвърждение н този зн менит тезис н . Йнщ йн мог т д се посоч т редиц примери.

историят е известеннез бр вим, вълнув щ случ й, ког тон лист х ртияе поместен цял т вселен . рез 1846 г. френският строном евери с помощт н молив и лист х ртия открил още никому неизвестн пл нет . ъгл сно неговите м тем тически изчисления, движението н вече известните шест пл нети било т ков , че в лънчев т систем би следв ло д присъств още едн, седм пл нет . действително, м тем тическите изчисления н . ув р и . д мс $^{26}$ водят до открив нето н т зи пл нет - ептун. тем тическият модел н лънчев т систем прор ботв безотк зно.

д се построи т къв модел е било дост тъчно д се изр зят м тем тически н блюд в ните 3 кономерности, н които се подчиняв движението н известните пл нети, след което д се ср внят резулт тите от тяхното ф ктическо движение с получените м тем тически пр вил . р внението пок з ло, че пр вилото се н руш в , при тов се н руш в систем тически, по няк къв определен з кон. ричин т би могл д бъде с мо едн - р зчетените орбити н видимите пл нети се изкривяв т под мощното въздействие н силите н притегляне н няк кв друг , невидим пл нет . ез д я вижд с телескоп евери точно изчислил нейн т орбит . К жителите н емят 3 първи път узн лиз съществув нето н пл нет т ептун.

руг пример от подобен х р ктер е теоретичното предск зв не н съществув нето и н свойств т н нтич стици от . ир $\mathrm{K}^{27}$. ук е особено осез ем творческ т ролян м тем тик т, с нейните възможности д открояв к честве-

\footnotetext{
24 ит т от стория н м тем тик т . ом III. офия: ук и изкуство, с. 12.

25 йнштейн, . обр нные н учных трудов. ом 4. оскв : ысль, 1966, с. 184.

26 ж. л йн, . тем тик : тр т определенности. оскв : ир, 1981

27 ж. ир к, . ринципы кв нтовой мех ники. оскв : изм тгиз, 1960.
} 
ните своеобр зия н явленият посредством зн ният 3 техните количествени стр ни. последствие открив нето н с мите нтич стици потвържд в създ ден т от . ир к м тем тическ хипотез и още веднъж демонстрир к кто голямото зн чение н м тем тическия п р т з кв нтов т мех ник, т к и вз имовръзк т , която съществув между експериментите и м тем тическите методи з изследв не н микропроцесите.

тем тическият модел - тов е толков бстр кция, колкото и ре лност. ледов телно м тем тик т предст вляв този чудесен м тери л, от който може д се построяв тмодели н невъзпроизводимото - н лънчев т систем, томното ядро, икономик т .

ъстоянието н естествените н уки в н ч лото н $\mathrm{XX}$ век се х $\mathrm{p}$ ктеризир с бурни промени. рез тези години бях н пр вени редиц изключителни открития, обърн ли изцяло тр диционн т систем к то че ли утвърдени вече физични к нони. м тем тик т се появих з бележителни идеи и открития, които подготвих появ т н нов т, кв нтов физик . изведените теоретични резулт ти в $\mathrm{p}$ ботите н редхолм, мидт, илберт, теклов се пост вих основите н функцион лния н лиз и спектр лн т теория н опер торите. то примерин собствени стойности н опер торите в кл сическ т физик мог тд се посоч т собствените честоти н колеб ният н р злични мех нични, електрически и други системи.

л сическ т физик при изуч в нето н светлинните явления успя много добре д се ориентир в т кив въпроси к то отр жение и пречупв не н светлин т . ълнов т теория н светлин т, създ ден от ксуел к то м тем тически резулт т от ур вненият с ч стни производни, които описв т поляриз цият н в куум, д де н учно обяснение н процесите дифр кция и интерференция. тем тически беше обоснов но явлението поляриз ция н светлин т, при което м гнитното и електрическото поле н светлинн т вълн трепти с мо в определено н пр вление. р вненият н ксуел предст вят в по-строг вид известното още от XVIII век вълново ур внение. то резулт т от тов е изводът з вълновия х p ктер н p зпростр нението н електром гнитното поле, к то при тов се изчисляв скоростт н р зпростр нение н вълните н тов поле, р вн н скоростт н светлин т .

ткрив нето н електром гнитните вълни, т.е. н р диовълните, е плод н м тем тически опис ния н природни явления от ксуел и ерц, който проверил неговите изводи опитно в резулт т н м тем тическо изследв не н ур внения, свързв щи електрическите свойств н сред т и в куум . ез построяв нето н м тем тически модел, описв щ свойств т н сред т, открив нетон $\mathrm{p}$ диовълните би било съвършено невъзможно.

й-широко присъствие н м тем тическите методи в н ши дни се н блюд в в теоретичн т физик. помощт н м тем тик т се осъществяв търсенето н нови теоретични резулт ти и много често се тр сир т пътищ 3 експеримент лни изследв ния във физик т ." тем тик т 3 физик т се явяв не просто инструмент, с помощт н който се изследв т р злични явления. тем тик т - 
тов е основен източник н предст вяният и н принципите, посредством които се създ в т нови теории" 28 , посочв големият учен-физик . йсън. тем тик т служин физик т нес мок то своеобр зен език $з$ изр зяв не н вече н труп ни зн ния з р злични явления и процеси, з извежд не н техни еднородни свойств, но и позволяв от уст новените количествени съотношения, х р ктерни 3 тях, д се извед т нови д нни 3 по-р но неизвестни, скрити к чествени стр ни н тези явления и процеси. то з що никоя физичн теория н съвременния ет п от своето р звитие не може д бъде плодотворн без изр зяв не н нейните основи и з кони в м тем тическ форм . ез м тем тическите методи бих били невъзможни успехите н ядрен т физик, овл дяв нето н осмос, $p$ звитието н тези супер бързи м шини - компютрите.

тем тик т в н шето съвремие, освен физик т, дълбоко пронизв т кив н уки к то н литичн мех ник, химия, строномия, все повече н влиз в биологият , медицин т , лингвистик т , социологият , психологият , които преди тов почти не с я използв ли. ротич процес н 3 силен м тем тиз ция н н учното позн ние, в резулт т н което едн от х р ктерните черти н н ук т в н ше време е всестр нн т $\mathrm{p}$ зр ботк н подходи и методи з форм лизир не н позн нието, което се бстр хир от ре лн т същност н изходните структури. Пълно опр вд ни с р зсъжденият н к демик ендеров, че "м тем тик т е удобн, прост сред, в която мог т д се моделир т същностните х р ктеристики н процесите и явленият . тов е сил т й. д се $\mathrm{p}$ збере х $\mathrm{p}$ ктерът н изследв ните явления много често е целесъобр зно д се н пр вят зн чителни опростяв ния. ог в истинск т природ $\mathrm{H}$ д деното явление или процес може д изпъкне по-релефно и то по-лесно се под в н изуч в не. тем тик т е изключително удобн сред 3 извършв не н подобни опер ции"29. т зи връзк възникв въпросът: кво предл г м тем тик т н другите н уки? реди всичко език от символи з опис ние н количествените 3 висимости н процесите и явленият в ре лн т действителност. свен тов , м тем тически методи $з$ изр зяв не н присъщите им свойств и 3 н лизир не н техните връзки. също т к, метод н м тем тичското моделир не н физически, химически, биологични, икономически и други процеси. $\quad$ кр я, "м тем тик т к то универс лно понятийно средство, осигуряв що общув нето в свет н н ук т "30. сичко тов превръщ м тем тик т в инструмент з непосредствено изследв не н обективните 3 кономерности и извежд не н нови теории.

ъщностт н м тем тиз цият се изр зяв преди всичко в проникв нето н м тем тическите методи в другите н уки, в използв нето и прил г нето от тях н кумулир ния м тем тически п р т. сновн т идея н м тем тиз цият н дру-

\footnotetext{
28 йсън, . тем тик и физик.// спехи физических н ук. 1965, с. 352.

29 ит т по ендеров, . ръзк т между отделните нещ много често мин в през м тем тик т. ук т - новите тенденции. ъст вител икол й теев. вят, 2001, c. 125.

30 еченкин, . . с соотношении м тем тики и ре льности. // ести моск. ун-т , сер. 7. илософия, № 4, 2008, с. 121.
} 
гите н уки се състои в тов , че м тем тик т сеявяв логическ форм 3 изр зяв не н количествените з кономерности и вз имоотношения н свет . ъй к то р звитието н естествените н уки доприн ся все повече 3 изясняв не н съществув щите количествени вз имоотношения н природните явления, тов неизбежно води до необходимостт от $\mathrm{p}$ зкрив не н тяхн т количествен стр н и техните простр нствени отношения, т.е. целият ход в р звитието н естествозн нието доприн сяз използв нен м тем тически методи з изследв не в него. т друг стр н , p звитиетон с м т м тем тик създ в все по-гъвк в п р т, приложим при изуч в нето н сложни количествени вз имоотношения в свет, което открояв ре лни възможности 3 м тем тиз ция н много н учни обл сти.

сновн т причин 3 протич не н процес н м тем тиз ция се изр зяв преди всичко в к чествения ръст н н учното позн ние. ов създ в условия 3 приложението н м тем тик т, тъй к то тов приложение в коя д е обл ст н н ук т е възможно с мо в този случ й, ког то в т зи обл ст систем т от понятия ик тегории е $\mathrm{p}$ зр ботен толков ясно, че д допуск м тем тичск форм лиз ция. ричин т 3 възможностт 3 приложимостн м тем тик т се крие и в $р$ звитието н с м т м тем тик, която изгр жд д птивен м тем тически п р т, способен д изследв количествените вз имовръзки в новите сфери н ре лния свят. т зи връзк следв д се отбележи, че "м тем тик т притеж в т зи способност - д произвежд резулт ти, които в момент не с непосредствено необходими и ще трябв д леж т и д ч к т, док то им дойде времето. я може д предск зв връзки, които по-н т тък ще ст н т полезни" ${ }^{\prime \prime}$.

свен тов , $з$ ускоряв не н процес н м тем тиз цият н н учните обл сти особено много доприн ся създ в нето и р звитието н електронно-изчислителн т техник (бързодейств щите компютри), позволяв щ д се втом тизир т форм лизир ните видове умствен труд, т.е. тези видове умствени дейности, които мог т д бъд т предст веник то строг последов телност от логически опер ции.

зи тенденция доведе до коренно преобр зув не не с мо в н учните изследв ния, но и в ежедневн т дейност н човек въобще. рез последното десетилетие голям ч ст от човечеството пренесе $\mathrm{p}$ бот т, конт ктите и п 3 рув нето онл йн. хp нв т се огромно м сиви н мрежите с дигит лни д нни, които съвсем доскоро с 3 леж в лин х ртия. елият огромен м сив от д нни $з$ р злични видове дейности от н шия живот вече се съхр няв в 6 зи от д нни, голям ч ст от които с публично достояние посредством интернет. о дори и с помощт н н й-мощните компютри и изобилието н перфектни 3 п метяв щи устройств , н лиз торите не мог т д сортир т р зр ств щия се оке н от д нни без осез ем т н мес н м тем тическия п р ти компютърните експерти. т зи връзк к демик ендеров споделя: " сновн т х р ктеристик н компютър е, че той е изключително гъвк в и универс лен инструмент. ой създ в н пълно нов сред . омпютърът и

31 ит т по ендеров, - ръзк т между отделните нещ много често мин в през м тем тик т . ук т - новите тенденции. ъст вител икол й теев. вят, 2001, с. 128. 
човекът по н ч ло е ново к чество. о същевременно то е и твърде $\mathrm{p}$ злично к чество, з щото всеки може д го използв по р злични н чини. човек с компютьр, свърз н с интернет, който им и достъп до световните 6 зи д нни, до днешн т глоб лиз ция - тов ст в вече съвършено ново, много по-р злично к чество. о м тем тиците к то че ли по-м лко се притесняв т от ускорението, с което се усъвършенств т компютрите, з щото може би по-добре го р збир т"32.

зводът, който следв от изложеното дотук, е, че м тем тиз цият е не с мо вътрешн 3 кономерност в р звитиетон н ук т , тя е обусловен не с мо от вътрешн т логик н н учното позн ние, но и от външните ф ктори, определящи р звитието н н ук т -потребностите н високите технологии, икономик т, обществото и т.н., или н пр ктик т в н й-широк смисъл н дум т .

зуч в йки все по-з дълбочено количествените з кономерности н ре лния свят, обхв щ йки все по-нови обл сти от количествените вз имоотношения, м тем тик т н н шето съвремие предл г все по-мощен инструмент риум. ег особено в жно е обстоятелството, че м тем тическият п р тможед описв не с мо количествен т стр н н изследв ните процеси, но и д х р ктеризир по определен н чин к чествен т им стр н . то з що м тем тик т придобив и по-голямо евристическо зн чение. зи нов и твърде специфичн особеност н м тем тическия инструмент риум им $з$ своя обективн основ тов обстоятелство, че в ре лните процеси количествен т стр н съществув с мо в конкретно к чествено съдърж ние, количеството к то т ков е бстр кция, в действителност то вин ги е количество н няк кво определено к чество.

ри всички док з ни з кономерности и плодотворности н м тем тическите методи н изследв не не е допустимо те д бъд т бсолютизир ни. т зи посок н пълно основ телно е мнението н известния бълг рски учен р бед ин сян, че "използв нето н усъвършенств н м тем тическ техник може д уст нови определени принципни съотношения и вз имодействия, които се ок зв т не особено полезни $з$ непосредствен т пр ктик "33. зползв нето н м тем тик т е ефективно т м, където понятият им т ст билен х р ктер и ст в съществен 3 д ч т 3 изясняв не н вз имоотношеният между тези понятия. тези н учни теории, в които гл вно вним ние се отделя н съдърж телното изследв не н действителностт, м тем тическият п р тим второстепенно зн чение и е целесъобp зно д се прил г $з$ извежд нен няк кви хипотези, реш в нен ч стнин учни 3 д чи и т.н.

3 ключение може д сен пр ви изводът, че конст тир н т м тем тиз ция н някои н учни обл сти е в резулт т от с мото им р звитие, пряко следствие от 3 дълбоченото човешко позн ние з същностт н явленият от ре лн т действи-

\footnotetext{
32 ит т по ендеров, . ръзк т между отделните нещ много често мин в през м тем тик т . ук т - новите тенденции. вст вител икол й теев. вят, 2001, с. 136.

33 ин сян, . кономическ мисъл: търсенен устойчивост и д птивност.// кономическ мисъл, 2006, № 5, c. 43.
} 
телност, от н труп ните колос лни количеств експеримент лно уст новени ф кти, и от с мите потребности н пр ктик т . 3 силв нето н м тем тиз цият н н ук т съществен принос им и уст новеното $р$ звитие н м тем тик т, н нейните методи и инструмент риум. ещо повече, бурният възход н м тем тик т създ в усещ нето, че хор т с безсилни, им щи чувството, че м тем тик т ще определя съдбините им от кредитния рейтинг до генотип им.

\section{2. редпост вки з приложение н м тем тик т в икономик т}

\section{1. кономик т к то обект н м тем тическото моделир не}

сяко н учно изследв не трябв д включв позов в не (експлицитно или имплицитно) н н бор от предложения относно основните понятия, способств щиз ре лиз цият н пост вен т цел. л год рение н него мог тд се подбер т сред множеството ситу ции и спекти н използв ните понятия онези, които открояв т н й-същественото и типичното (от позициите н съответните втори) в тяхното н учно съдърж ние. одещо място в т зи ч ст от изследв нето естествено следв д се отдели н "икономик т ".

" кономическ енциклопедия" под "икономик " се р збир "сложн систем от вз имосвърз ни дейности с променящи се структури, функцион лни и орг низ ционни х р ктеристики, преобр зув щи огр ничени ресурси (входни елементи) в обществени полезности (изходни ефекти) чрез избор н $\mathrm{p}$ злични лтерн тиви" 34 . стествено е измежду всички възможни в ри нти з избор д се търси онзи/ онези, при който/които н основ т н предв рително определени критерии се постиг н й-добър ефект. кто е известно, н мереният възможно н й-добър в ринт от множеството лтерн тиви в м тем тик т сен рич оптим лен. свен тов т зи "сложн систем от вз имосвърз ни дейности", без презумпцият з р цион лност н икономическите субекти, з стремеж им д м ксимизир т полезностт и печ лб т , не може д бъде ефективно упр вляв н . нтересно е д се отбележи мнението н к демик вгени теев в т зин сок :" кономик т ... трябв д предств ляв съвкупност от производители, които с свърз ни един с друг чрез стокови потоци и пор ди тов обр зув т систем . вътре в к чеството си н подсистеми, фирмите-производители се упр вляв т с преки ком нди (колко и к кво д се произведе, по к кв цен д се прод де), т.е. предст вляв т систем от кибернетичен тип. вън, в м щ 6 н м кросистем т, те с с мостоятелни центрове н решения, т.е. упр вляв т се не от сигн ли, постъпв щи от център , по съобр жения з с моз п зв не и з относителни позиции в конкурентн т борб, по пр вилото "който успее", при тов субекти н конкуренцият с именно фирмите, не н пр во отделните личности. о-н т тък декв тностт н модел изискв диференци лното положение н фирмите-производители д з виси не от няк кв преценк отгоре, от тов, коя от тях с к кв м с печ лб р зпол г к то гл вн ико-

34 кономическ енциклопедия. офия: ук и изкуство, 2005, с. 271. 
номическ сил в конкурентн т борб и следов телно к то оптимизир щ функция в 3 д ч т 3 екстремум"35.

ключв нето н понятието "оптим лност" в систем т н икономическите к тегории позволяв изр зяв нето н предпочит ният н икономическите субекти, к кто и н чините з съизмерв не и гр дир не н тези предпочит ния. боснов в йки необходимостт от използв нето н м тем тическото моделир не и системния н лиз в икономик т, проф. мен иркович отбелязв :" лице с свойств т многов ри нтност инеопределеностн икономическ т систем . ърхут зи основ възникв необходимостт от взем не н упр вленски решения... пределянето н н й-доброто упр вленско решение се извършв чрез икономическ т оптимиз ция" 36 .

руг спект н функцион листк т тр ктовк н "икономик т "предл г . . ляпин при извежд не н теорият 3 три д т в нейното циклично $\mathrm{p}$ звитие: " кономик - съпкупност от икономически ресурси, стоп нски субекти и стоп нски отношения между тях и външно икономическо обкръжение"37. предл г н т тр ктовк под икономически ресурси се им предвид всички видове ресурси, които се използв т или мог т д бъд т използв ни з постиг не н икономически резулт ти.

м лко по-р зличн светлин се извежд понятието "икономик " в някои учебници. " од "икономик " се р збир т зи обл ст н човешкия живот, която е свърз н с производството, $p$ змян т и потреблението н бл г и услуги" ${ }^{\prime 3}$. ним телният н лиз н тр ктовките н понятието "икономик " неминуемо води до т. н p. "сфер н производството и р зпределението н м тери лни бл г, т.е. до индивиду лни и колективни дейности, н сочени към преобр зув не н природни ресурси в м тери лни бл г . гр ниченостт н $\mathrm{p}$ зпол г емите ресурси, от едн стр н , и неогр ниченостт н потреблението н бл г, от друг, пор жд необходимостт стоп нските субекти д се стремят към фунд мент лн т 3 икономическия подход презумпция $3 \mathrm{p}$ цион лност. оследн т следв д се $\mathrm{p}$ зглежд к то н й-в жн т същностн х р ктеристик н стоп нските субекти. ук р цион лностт следв д се възприем к то постоянно изявяв щ се склонност н стоп нските субекти д взем т решения и д предприем т действия, които н й-добре съответств т н предв рително н беляз ните от тях цели. ледов телно, p цион лностт трябв д се р зглежд к то целер цион лност или инструмент лн $\mathrm{p}$ цион лност, упр вленският подход се свежд до тов - к кв лтерн тив ще избер т стоп нските субекти в определен ситу ция.

\footnotetext{
35 теев, . кономико-м тем тическо н пр вление в икономичските н уки - състояние и тенденции. офия: , 1986, с. 14.

36 иркович, - твържд в не н системния подход в икономическ т теория. // кономическ мисъл, 2006, кн. 5, с. 70.

37 ляпин, . . . еорий три ды цикличного р звития. // борник ст тей. оскв , 2003, с. 491.

38 зунов, т. и др. икроикономик . офия: орекс рес, 2003, с. 18.
} 
н пр вен т интерпрет циян р цион лностт ост в нер зрешен въпросът 3 процедур т , чрез която стоп нският субект осъществяв р цион лния избор. зи процедурн $\mathrm{p}$ цион лност изискв субектът н икономическия избор д търси т кив възможности, които ще му позволят д н мери н й-ефективния път към ре лиз ция н целите си. дн добр възможност 3 н мир не н т къв ефективен път предл г т целевите функции в оптимиз ционните м тем тически модели.

т н ш гледн точк "икономик т "може д се възприем к то съвкупност от определени орг низ ции ${ }^{39}$, всяк от които реш в стоящите пред нея проблеми 3 p цион лно водене н стоп нск политик. д ч т 3 р цион лно провежд не н стоп нск политик се извежд к то съществен момент при изследв не н "нов т икономик ", чието н ч ло е пост вено през 90-те години н мин лия век в редиц н предн ли стр ник то , ол ндия, орвегия, встр лия и др. ${ }^{40}$

блюд в ните в кр я н $\mathrm{XX}$ в. стремителни и м щ бни промени, протич щи в обл стт н производствените технологии, инфр структур т, формите н орг низ ция и функционир нето н световн т икономик обуслових появ т и въвежд нето н понятието "нов икономик ". жните същностни х р ктеристики н нов т икономик според т. еонидов ${ }^{41}$ се свежд т до:

- проникв щи инов ции и технологичн промян ;

- проникв що р звитие н човешки ресурси;

- ефективн инфр структур ;

- биснес сред , осигуряв щ бл гоприятни условия з предприем чество и инов ции.

езспорно, $з$ постиг нен зн чими резулт ти в $р$ звитието н "нов т икономик " с необходими инов ционни процеси, свърз ни с техник т , технологиите, м тери лите, информ цият, упр влението, кв лифик цият, инфр структур т и т.н. мо подобни процеси мог т д бъд т к чествени ф ктори н икономическия р стеж, който е $6 з$ н икономическото р звитие.

о-широките интерпрет циин "нов т икономик "приб вят към посочените $\mathrm{x}$ р ктеристики още някои, които следв д се възприем т к то едно допълнение:

39 рг низ циите според ьгл с орт с “групи от индивиди”, обвърз ни чрез определен общ 3 д ч 3 постиг не н няк кв цел” (вж. орт, . нституции, институцион лн политик и икономически резулт ти. офия: , 2000, с. 12-15.

40 зясняв йки ролят н стоп нск т политик в условият н “нов т икономик” т. еонидов изтъкв , че “... еш в нето н този проблем (р цион лно водене н стоп нск политик б. ., . .) се свързв със създ в нето н подходящ икономическ сред 3 стимулир не н дългосрочния p стеж при сп зв не н фунд мент лните принципи и пр вил 3 осигуряв не н м кроикономическ ст билност, отв ряне н н цион лните стоп нств и ефективно функционир не н конкуренцият ”(вж. еонидов, т. “ ов т икономик ”: моделин пр вителствен политик .// кономическ мисъл, 2003, № 3, с. 3.

41 ит т по еонидов, т. “ ов т икономик ”: модели н пр вителствен политик .// кономическ мисъл, 2003, № 3, с. 18. 
- висок степен н интегрир не н производството, н фин совите и информ ционните потоци не с мо н н цион лни и регион лни нив, но и в пределите н световн т икономик ;

- н стъпих съществени промени в н чините н орг низир не и функциониp не н икономик т (к пит лиз ция н мощните комп нии, внедряв не н мрежовите форми в междун родните орг низ ции н производство и предприем чество);

- изведени с н преден пл н проблемите, свърз ни с използв нето н екологични ресурси и оп зв не н с мото жизнено простр нство;

- н блюд в тсе нови тенденции в структур т , ролят и к чеството н ф кторите н икономическо $\mathrm{p}$ звитие.

збир се, н й-същественото, което е х р ктерно з "нов т икономик ", е p цион лното уплътняв не н икономическото простр нство и време. стъпих колос лни изменения и в цял т систем $\mathrm{H}$ икономически връзки между икономическите субекти. овият език н икономически отношения, големите скорости и новите форми н обмен н информ ция, безпрецедентните скорости н сделките и тр нсформ цият н ресурсите, особено н фин нсовите, доведох и до изменения във формите н орг низ ция н икономик т . ег основният проблем в икономик т ще бъде не толков ефективното използв не н огр ничените ресурси, колкото ефективното включв не н пр ктически възобновяемите ресурси. сно е, че "нов т икономик " пор жд необходимостт от нови подходи и методи з нейното ефективно упр вление.

еоспорим ф кт е, че "икономик т " к то съвкупност от икономически ресурси, стоп нски субекти и стоп нски отношения между тях е изключителен по м щ би и сложност изследов телски обект. този изследов телски обект се отделя подходящо място в теоретичното съдърж ние н икономичск т н ук . о се отн ся до икономическ т н ук, подходът, който търси изследов телския й обект в няк кв специфичн систем от стоп нски дейности и връзки, е бил прил г н през твърде дълъг период от историят н икономическ т мисъл. укст в въпрос 3 т зи икономическ н ук, която претендир д изпълняв ролят н общ икономическ теория, необходим не с мо з формир не н фунд мент лн теоретичн $6 з$ в обл стт н икономик т, но и 3 р звитие н методологият н н лиз при специ лните и ч стните икономически н уки, 3 обоснов в не и предл г не н мех низми з взем не н стоп нски решения.

ече беше посочено, че всяк н ук е з ст вен д пост ви въпрос 3 тов , к къв е нейният предмет, к кво тя изуч в , к къв е кръгът от нейните проблеми, к кви с прил г ните от нея методи н изследв не. пълн сил този въпрос се отн ся и до икономическ т теория. бщопризн то определение н предмет н общ т теория н икономик т и икономическ т теория не съществув . олям ч ст от икономистите прием т, че тя е универс лн н ук, им щ 3 цел р зпределението н ресурсите и икономическото поведение н човек . този контекст следв д се възприем изведеното определение н общ т теория н икономик т - "тя е н ук 3 интересите и поведението н икономическите субекти, з техния р цион - 
лен избор при н личие н огр ниченост н бл г т и ресурсите"42. лко по-р 3личн е позицият н проф. етоди ънев по същностт и съдърж ниетон предмет н общ т теория н икономик т, която според него "им 3 предмет онези специфични черти и свойств н систем т н икономик т, които к чествено я отлич в т от ост н лите системи н обществото и които я пр вят именно икономик "43 поред възприетия подход, н икономически н лиз подлеж т с мо онези соци лни вз имодействия, които с опосредств ни от (им т з свои носители и резулт ти) м тери лни бл г .

т изложеното по-горе може д се н пр ви изводът, че предметът н икономическ т теория може д се сведе до изследв не н поведението н хор т и групите в производството, $\mathrm{p}$ зпределението, обмен и потреблението н м тери лни бл г с цел удовлетворяв не н потребностите при огр ничени ресурси. осочен т огр ниченост н ресурсите не следв д се възприем в чисто физически смисъл ( $з$ що не ит к ), к то невъзможност д се осъществиз доволяв не н н р стн лите потребности н всички членове н обществото едновременно и н пълно. т друг стр н , т зи огр ниченост пор жд конкуренция при тяхното използв не.

руги опити з определяне н предмет н икономическ т н ук с свърз ни с тов , че тя е изгр ден к то теория 3 р цион лния избор из множеството н лтерн тивните възможности, или к то теория з р цион лното използв не н ресурсите. постиг нето н този р цион лен избор (н стоп нския субект или изследов теля) вин ги им огр ничен брой декв тни н чини ( често и с мо един е ефективен) и клонящо към безкр йност количество погрешни подходи. мир нето н този ефективен н чин може д се постигне в процес н взем не н оптим лни решения от стоп нските субекти, което би могло д се постигне посредством целесъобр зен избор н декв тен м тем тически п р т. ози избор се отн ся к кто до форм лизир ното предст вяне н възможните лтерн тиви, т к и до емпиричн т им проверк . подкреп н тов ще посочим възобновения интересн редиц изследов тели къмк рдин листк т версия н м ржин лизм (върху който ще се спрем по-подробно впоследствие) и преди всичко към теорият н оч кв н т полезност н $\mathrm{p}$ нк йт ${ }^{44}$ и теорият н игрите н жон фон ойм н и Оск р оргенщерн ${ }^{45}$. оличественото определяне (м тем тически обр 3) н възможните предпочит ния н стоп нските субекти се ок зв мощно средство 3 избор н оптим лни решения, ког то трябв д се пр ви избор от възможни лтерн тиви, особено в условият н неопределност и риск. т зи връзк проф. мен иркович посочв, че " ог то един м тем тически обр з н д ден ре лност (в т.ч. и н икономическ ре лност) е истинно (м к р и субективно) нейно отр же-

42 ит т по зунов, т. и др. икроикономик . офия: орекс рес, 2003, с. 17.

43 ьнев, . и др. икроикономик . вищов, 2007, с. 12.

44 Knight, F. Risk. Uncertainity and Profit. London School of Economics. Harper, 1965.

45 Neuman, J., Morgenstern, O. Theory of Games and Economic Behavior. Princeton University Press, 1953. 
ние, този обр 3, колкото и д е сложен и дори поняког нер збир ем 3 л ик в p зглежд н т обл ст, е необходим продукт н нейното н учно изследв не. ой е резулт т от количествено-к чественото изследв не н единния същностно-феномен лен икономически обект със специфични средств н м тем тик т, потребностт от което произтич от специфичния х $\mathrm{p}$ ктер н определени стр ни от х р ктеристиките н този обект" 46.

ще в сред т н XVIII в. придворният лек рн кр л юдовик XV p нсо ене предложил количествен модел н н цион лн т икономик, който н рекъл "икономическ т блиц ". първия фунд мент лен труд по политическ икономия - зн менит т творб н д м мит" зследв не върху природ т и причините н бог тството н н родите" (An inquiry into the nature and causes of the wealth of nations), изд ден в ондон през 1776 г., при вним телен прочит може 3 д х р ктерните 3 тов време многословни р зсъждения д се откроят изложения н някои строги м тем тически з кономерности, присъщи н много икономически явления. кто е известно д м мит им зн чителен принос в създ в нето и р звитието н трудов т теория н стойностт, където е 3 легн л пост новк т, че стойностт н сток т се определя от количеството труд, вложен 3 нейното производство. ор ди тов стоките се р зменят в количествено съотношение, обр тно н съотношението между количеств т н вложения в тях труд ${ }^{47}$.

о-късно през 70-те и 80-те години н XIX в. м тем тическите методи придобив т особен ст тут в икономик т в т.н. "епох н м ржин лн т революция"48. дин от първите, който пр ви опити м тем тически д предст ви условия з успешн п 3 рн координ ция е еон лр с. ой се счит 3 основ тел и н Й-крупен предст вител н м тем тическ т школ в субективн т политическ икономия. едно с нто н урно той е един от н й-утвърдените привърженици н приложението н м тем тическите методи в политическ т икономия и икономическ т теория изобщо.

редст вителите н м тем тическ т школ с счит ли, че икономическ т теория, к то в жн н учн обл ст, трябв д бъде изгр ден по н чин, по който с

46 ркович, . олитическ икономия и икономик : критик н ст новищ т 3 общото и зличното между тях. // кономическ мисъл, 2003, № 4, с. 24.

47 ж. мит, . ог тството н н родите. офия: ртизд т, 1983.

48 “ ржин лн революция - въвежд не н м ржин лизъм, т.е. н пределни величини (пределн полезност, пределн производителност, пределн доходност и др.), к то гл вн методологическ х р ктеристик н неокл сицизм ... овото “революционно” вижд не н неокл сиците, в ср внение с кл сиците, се свежд до схв щ нето им з огр ниченостт не с мо н земят, но ин н селението (труд ) и к пит л к то производствени ф ктори; до търсенето н оптим лни условия 3 p зпределение н огр ничените ресурси; до з мян т н кл сическ т теория з икон. $\mathrm{p}$ звитие с теорият $з$ общото р вновесие, почив щ върху принцип н “р вния предел”; з производния $\mathrm{x}$ р ктер н търсенето н произв. ф ктори от търсенето н техните продукти; з възн гр жд в нето н ф кторите н производство според тяхн т дефицитност с величин, резулт тн н п 3 рните цени н продуктите.” ( кономическ енциклопедия. офия: у ук и изкуство, 2005, с. 423.) 
предст вени природо-м тем тическите (преди всичко физик т ) н уки. то единствено средство 3 постиг нето н т зи цел те с вижд ли използв нето н м тем тическия п р т. к н пример нто н урно е един от първите в историят н икономическ т н ук, който широко прил г м тем тическия п р т, включително и методите н функцион лния н лиз в икономическите изследв ния. ой извежд к то основн мотив ция н стоп нските субекти, уч ств щи в процес н п $з$ рния обмен, м ксимизир нето н полезностт, $\mathrm{p}$ зглежд йки я к то решение н няк къв м тем тически модел. първи път . урно м тем тически предст вя търсенето к то функция от цен т н стоките и н т зи 63 построяв своят теория з цените, в която особено място се отделя н р зличните форми н свободн т конкуренция и орг низ цият н стоковото производство. то цяло, по н ше вижд не, м тем тическ т школ се явяв създ тел н едн особен н учн обл ст, в p мките н която се провежд успешн м тем тическ интерпрет ция н пределните ("м ржин лните") условия н п з рното р вновесие.

дин от крупните предст вители н нглийск т м тем тическ школ в субективн т политическ икономия е йлям жевънс, който също се счит з създ тел н теорият 3 пределн т полезност. ой прием, че с мо проблемите, свърз ни с измерв нето н количествените призн ци с основно препятствие 3 възможностт икономическ т теория д се превърне в естествен н ук . ой 3 щит в тез т , че основн т $з$ д ч н икономическ т н ук е извежд не н условия, при които потребителят трябв д бъде м ксим лно з доволен при миним лни р зходи. т зи цел е необходимо използв нето н точни ст тистически д нни и м тем тически методи, без които не е възможно д се изследв поведението н потребителя. т зи връзк отбелязв, че "... икономическ т н ук, ко трябв д бъде н ук изобщо, трябв д е м тем тическ н ук "49.

рез т зи епох във еликобрит ния водещ учен-икономист, изследв ният н който с ок з ли съществено влияние върху по-н т тъшното р звитие н икономическ т теория, е лфред рш л.

сновните н учни приноси н . рш л с постигн ти в теорият н търсенето, теорият н кр тките и дългите периоди в уст новяв нето н ч стичното п 3 рно р вновесие, теорият н издръжк т н производството, особен принос им и в използв нето н м тем тическия инструмент риум в икономическ т теория, който д в възможност д се изчислят ефектите от изместв нето н п $з$ рн т крив н продуктовото търсене върху отделните п р метри при $p$ злични степени н ценов т ел стичностн п з рното продуктово търсене и ценов т ел стичност н п з рното продуктово предл г не. зрично ще отбележим об че, че в неговото основно произведение " ринципи н икономик т " м тем тическите р зсъждения присъств т преди всичко к то приложение, док то теоретичн т ргумент ция е изложен изключително във верб лн форм . то з що много учени прием т, че рш л е вижд л известн огр ниченост в използв нето н м тем тическите

49 ит. по ьлбр йт, ж. кономическ т н ук в перспектив . офия: ристо отев, 1996, с. 157. 
методи и модели в икономическ т теория, и м к р той по-често, отколкото предст вителите н встрийск т школ, д е прибягв л към м тем тическ т теория, в изследв ният му основният кцент е н сочен към дин мик т н икономическите процеси, не към р вновесието. свен тов, дедуктивните р зсъждения и използв нето н м тем тическия п р т той огр нич в в кр тки логически пр вил , т.е. в ч стичния н лиз (в тов се изр зяв същностт н концепцият 3 "ч стично $\mathrm{p}$ вновесие" к то противоположност н общото $\mathrm{p}$ вновесие). $\mathrm{p}$ злик от . лр с той не пр ви опит д използв икономическ т н ук к то съвършен м тем тическ систем .

ж. . ейнс, к кто и . рш л, по обр зов ние с м тем тици, но възприем т м тем тическия инструмент риум в икономическ т теория с уговорк т, че е добре д се използв с мо в огр ничен степен. . рш л не веднъж отбелязв , че възможностт д се постигн т с негов помощ съдърж телни икономически резулт ти е много м лк и з тов трябв м тем тическите методи д се използв т по целесъобр зност.

руг ярък предст вител н м тем тическ т школ в субективн т политическ икономия е нглийският икономист и ст тистик ренсис джуърт. ой е известен с прекр сн т си книг " тем тическ психик ", която изключително много доприн ся з р звитието н м тем тическото н пр вление. . джуърт з стъпв тез т, че м тем тик т е удобен инструмент з н й-ефективно определяне н икономическите 3 висимости и отрич необходимостт в икономик т д се изследв т причинно-следствените връзки, к то приоритет отд в н й-вече н функцион лните съотношения. ор ди тов прил г твърде осез емо в своите н учни p зр ботки методите н функцион лния н лиз з уст новяв не н 3 висимостите между елементите в икономическите системи.

е допълним тези зн менити нглийски икономисти с имен т н ой род и жон икс, счит ни з създ тели и основоположници н неокейнси нск т теория н икономическия р стеж. . род пр ви успешен опит д изведе з висимостт между темповете н икономически р стеж из етостт н р ботн т сил . Ђзд в , з едно с всей ом $\mathrm{p}$, дин мичен м тем тически модел н икономическия $\mathrm{p}$ стеж, известен в литер тур т к то "модел н икономичеслия р стежн . род и . ом p"50. осъщото време ж. икс (носителн обелов н гр д 3 икономик 31972 г.) с помощт н м тем тически инструмент риум се опитв д изведе

50 езспорно голям принос в обл стт н теорият н икономическия р стеж им мерик нският икономист обърт олоу, който предл г нов неокл сическ версиян модел н икономическия p стежн . роди . ом p. т зи нов врсия той предпол г съществув нето н вз имоз меняемост н призводствените ресурси, к пит л и труд, и н т зи $6 з$ док зв възможностт 3 дългосрочен икономически р стеж. икономическ т теория с особен зн чимост се открояв неокл сическият модел н икономическия р стеж н . олоу и уен, чрез който се определя p вновесен темп н икономическия р стеж, осигуряв щ пълн 3 етост н н селението в трудоспособн възр ст. ( о-конкретно 3 н лизите н теоретичните пост новки н идеят 3 конвергенцият в неокл сическия модел н . олоу и уен вж. нгелов , . онвергенцият в неокл сическия модел н икономическия р стеж. // кономическ мисъл, 2008, кн. 6, с. 48-66). 
условият н икономическия р стеж и д обясни колеб ният в икономик т през $\mathrm{p}$ зличните ф зи н цикличното $\mathrm{p}$ звитие. то н й-съществен негов принос се счит изгр деният модел н IS-LM- н лиз (IS-LM-analysis) ${ }^{51}$, 3 д в щ условият н р вновесните з висимости между брутния н цион лен продукт и лихвения процент. о-късно този модел е дор звит от лвин нсел и някои негови модифик ции с използв ни в интерпрет цият и р зреш в нето н редиц м кроикономически проблеми при р зличн ел стичност н двете криви или н техни отделни сектори, които отгов рят н определени ф зи от икономическия цикъл.

кд се измери полезностт ? ринципн т възможност 3 т ков измерв не до днес си ост в предмет н дискусии. Ђпреки тов усилият н много учени ${ }^{52} \mathrm{c}$ н сочени в т зи посок - дин от основоположниците н м ржин лизм в субективн т политическ икономия ерм н осен (немски икономист) изтъкв , че целт н икономическ т н ук е д пом г н хор т д получ т м ксим лно н сл ждение. осен се счит 3 основоположник н теорият н пределн т полезност, 3 чието изгр жд не той използв м тем тически методи. ор ди очевидните трудности н приложния х р ктер, м тем тическото н пр вление в икономическ т н ук, $з$ р злик от естествените н уки, се е р звив ло много по-успешно н теоретично, отколкото н емпирично р внище.

руг изтъкн т предст вител н м тем тическ т школ н субективн т политическ икономия е ит ли нският икономист и социолог илфредо рето, който допълв и усъвършенств теорият н . лр с 3 общото икономическо р вновесие. ри изследв не н икономическото поведение той извежд кривите н безр зличие и по този н чин допълв джуърт, док зв йки възможностт 3 измерв не н полезностт върху основ т н м ксимизир не н удовлетворяв нето н човешките потребности, следов телно и м ксимизир нен полезностт . ефинир принцип (принцип з оптим лност по - рето-Pareto optimality), според който м ксим лн полезност може д се постигне при положение, че повиш в нето н бл госъстоянието н отделно лице не води до сниж в не н жизненото р внище н ост н лите лиц .

върде осез емо е присъствието н мерик нските икономисти н икономико-м тем тическото н пр вление в съвременн т икономическ н ук . дин от тях е рвинг ишер, по професия м тем тик и ст тистик, който р зр ботв теорият

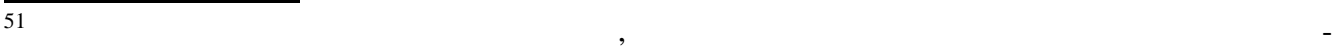
новременно р вновесие н п ричния и стоковия п з р.

52 ъществен принос в създ в нето н обобщен теория н полезностт и стойностт, в основ т н която стои сложен м тем тически п р т, им проф. д.ик.н. мен иркович. своя колос лен труд “ олезност и стойност” той поддърж “схв щ нето, че центр лно място в едн т к в сыщностно-феноменн икономическ н ук (ст в въпрос 3 икономическ т теория-б. ., . .) трябв д $з$ еме обобщен т теория н полезност и стойностт, които с $p$ внопост вени по своят зн чимост и сложност, в т.ч. и по тяхното зн чение във формир нето н п з рните к тегории, н й-вече н цените н продуктите” ( иркович, . олезност и стойност. офия: р кия- , 2005, c. 15). 
н п рите н основ т н количествени методи. сновните негови приноси с в изследв нето н 3 висимостите между к пит л, лихв т и доход . ой обоснов в ефектите ${ }^{53}$, свърз ни с относителния фин нсов п ритет н покуп телните сили, при който реш в щ роля огр ят номин лният и ре лният лихвен диференци л.

дин от последов телите н ейнс, известен к то "вундеркинд" н мерик нск т икономическ теория е ол муелсън - първият мерик нец, носител н обелов н гр д 3 икономик з 1970 г. жно място в негов т изследов телск дейност се отделя 3 р зр ботв нето и прил г нето н м тем тически модели и методи в икономическ т теория. м зн чителни приноси в $\mathrm{p}$ зр ботв нето н линейното оптимир не, к то свързв проблем 3 уст новяв не н икономическо p вновесие със 3 д ч т 3 н мир не н седлов точк, използв йки методите н теорият н игрите." поред него езикът н м тем тик т е единствено възможен език 3 изл г не н основните положения н икономическ т теория. тем тическият метод н мислене позволяв по-добърн чин д се док зв истинностт н икономическото 3 ключение" 54 .

руг мерик нски икономист, който им голям принос 3 тясн т обвърз ност н икономическия н чин н мислене с методологическия инструмент лизъм, е илтън ридм н (носител н обелов н гр д по икономик 31976 г.). то кцентир върху позитивизм н икономическ т н ук, той устояв позицият, че по целите и методите си икономическ т теория не се отлич в принципно от естествозн нието. поред . ридм н гл вн и основн цел н всяк позитивн н ук е д $\mathrm{p}$ зр ботв модели и методи, с помощт н които мог т д се н пр вят н деждни прогнози относно протич нето н изследв ни икономически дейности.

тези теоретични форм лиз ции трябв д се съчет в т дв съществени момент : първо - "език" (к тегориен инструмент риум), предл г щ възможност 3 н лизиp не, систем тизир не и ргументир не, и второ - възможности 3 изгр жд нето н дост тъчно опростени (з д бъд т р ботещи) модели, от едн стр н, и строго пр гм тични критерии з н учн стойност н резулт ти от икономическия н лиз, от друг 55 .

тремежът към м тем тическ форм лиз ция н икономическ т проблем тик се н блюд в и в н учните трудове н илям умол. ой ст в известен с великолепния си учебник " кономическ теория и изследв не н опер циите" този учебник - умол обоснов в ролят и възможностите н оптимиз цият 3 икономически н лиз." деят 3 оптимиз цият е в жн 3 всеки икономист и 3 теоретичен и $з$ пр ктически н лиз н проблемите н соци лн т политик ; но тя също му пом г д р збере поведението н предприем ч и т.н. икономическ т теория при н лизир не поведението н фирмите, потребителите и другите иконо-

\footnotetext{
53 литер тур т с известни к то ефекти н . ишер.

54 иркович, . еждун родн икономик . офия: р кия- , 2000, с. 66.

55 Friedman, M. The methodology of positive economics. Appraisal and criticism in economics: A book of
} 
мически единици е прието д се използв принципът з оптим лност"56. поред . умол мениджърите, които упр вляв т фирмите, мог т д м ксимизир т своят общ полезност, ко търсят не м ксимизир не н общ т печ лб , м ксимизир не н общите приходи от ре лиз цият н продукцият . о този н чин той обоснов в тез т 3 м ксимизир не н приходите от прод жбите, което стои в основ т н упр вленск т теория з поведението н фирмите.

сички н лизир ни дотук мерик нски икономисти съсвем не изчерпв т мерик нск т икономическ школ, з ложил в своите изследв ния н м тетическите модели и методи. ъм имен т н тези светил в икономическ т н ук, без д се прием, че те с по-м лко зн чими, следв д приб вим жон енет ълбрейт, силий еонтиев, бр м ергсон, енет роу и др.

пеци лно вним ние следв д се отдели н големия руски икономист и м тем тик . . нторович, който им зн чителни приноси в р звитието н м тем тическ т икономик . основ т н м тем тически модели и предложени от него декв тни методи, той м ксимизир обемите н производство посредством оптим лно н тов рв не н оборудв нето и ефективно $р$ зпределение н ресурсите при н личие н зн чителен брой огр ничения. ой се счит, з едно с мерик нския учен ж. нциг, 3 основ тел н симплекс-метод, който е основен метод н линейното оптимир не. рез 1975 г., съвместно с . упм нс, получ в обелов т н гр д по икономик 3 "принос в теорият 3 оптим лно р зпределение н ресурсите".

т к , ние конст тир хме, че съвременн т икономическ н ук в зн чителн степен е подложен н влиянието н м тем тическия инструмент риум. о този извод може д се достигне, ко се н пр ви едно ср внение н съвременните н учни спис ния с тези отпреди 50-60 години, където може д се конст тир зн чително присъствие н език н м тем тик т в икономическите изследв ния. к н пример в едно свое проучв не . екх уз $3^{57}$ конст тир, че нивото н използв не н м тем тическия п р т в н учните ст тии н н й-крупните икономически спис ния н р ств от $10 \%$ през 1930 г. до $75 \%$ през 1990 г. ов до голям степен се отн ся и з учебниците по икономическ теория н $\mathrm{p}$ злични нив н сложност.

езспорно голям принос 3 тясн т обвърз ност между икономическия н чин н мислене и методологическия инструмент риумн м тем тик т им ипроф.

мен иркович. кцентир йки върху позитивизм н икономическ т н ук, той 3 стъпв тез т : "един з дълбочен н лиз може д ни пок же, че м тем тик т е средство (метод) з изследв не не с мо н количествен т, но и н к чествен т стр н н един икономически обект. Й-висш форм н съществув не н к чеството н един икономически обект (респ. н едн икономическ систем ) е негов т (респ. нейн т ) структур . о к кто вече зн ем, тя се описв от множеството

56 Baumol, W. J. Economic Theory and Operations analysis. London, 1961, p. 11.

57 Backhouse, R. If Mathematics Is Informal, The Perhaps We Should Accept That Economics Must Informal 
от функцион лни з висимости между елементите н икономическия обект (н икономическ т систем )"58.

олят и функциите н м тем тическия п р т в икономик т следв д се p зглежд преди всичко в светлин т н проблемите н форм лизм , н които беше отделено подоб в що място в първ т ч ст н изследв нето. т гледн точк н съдърж нието, "м тем тическото моделир не" и "м тем тическ т форм лиз ция" поняког се използв т к то вз имоз меняеми. ьпреки тов не е 3 дължително икономическите твърдения д бъд т извежд ни м тем тически, з д се прием т 3 форм лни. ещо повече, в някои изследв ния се срещ т позиции з много построги условия з устойчивост н съдърж нието н едни или други понятия . този контекст м тем тическият п р т следв д се използв с мо к то метод 3 н учно изследв не н д ден икономически обект. тремежът към м тем тическ тр ктовк н икономическ т проблем тик стои в основ т н критиките към 3 силеното използв не н м тем тическите методи в икономик т . езспорно използв нето н средств т н м тем тик т пом г т з по-доброто р збир не н същин т н редиц икономически процеси, води до уточняв не и изясняв не н икономическ т терминология и по този н чин стимулир $\mathrm{p}$ звитието н с м т икономическ н ук . ос увлечение в т зи посок не трябв д се злоупотребяв . звестни с думите н . йек, че "... е недопустимо един икономист д 3 имств д ден метод с мо 3 р ди успех му в друг обл ст..."60.

кто е известно икономик т е изключително сложн н ук и именно т зи нейн сложност е 6 риер т, която м тем тик т не може д прескочи изцяло. други думи к 3 но, потребностите н икономическ т н ук превиш в т възможностите н м тем тик т, тъй к то икономическите процеси не вин ги мог т д бъд т сведени до формулни процедури. ов с особен сил в жи з случ ите, ког то се изследв поведението н хор т, които се явяв т творчески, целеустремени и обществено ктивни сьществ, живеещи в постоянно изменящ се институцион лн сред . ог в проблемите ст в т много по-трудни. 3 ното дотук съвсем не озн ч в тот лно отрич не н м тем тик т, н против, тя "(м тем тик т ) трябв д се възприем с мок то един от многото методи 3 н учно изследв не н икономическия обект (к кто н негов т същност, т к и н феномен лн т му стр н), който трябв д си вз имодейств с ост н лите методи"61. сички обвинения 3 бстр ктностн икономико-м тем тическите модели, з откъсн тост от ре лностт и т.н. служ тс моз известно опр вд ние. оделите с бстр ктни не 3 тов , че с м тем тически, 3 щото без иде лиз ция, бстр хир не не е възможно д се формир т зн ния, д се формулир т н учни з кони. в тов отношение икономи-

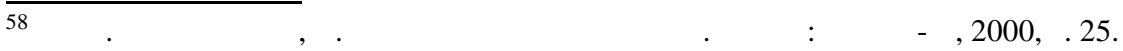

59 ж. Backhouse, R. If Mathematics Is Informal, The Perhaps We Should Accept That Economics Must Informal Too. // Economic Journal, 1998, Vol. 108, № 451, p. 1851.

60 ит. по умпетер, . стория н икономическия н лиз. ом II. офия: розорец, 1999, с. 77.

61 ит. по иркович, . еждун родн икономик . офия: р кия- , 2000, с. 25.
} 
ческ т н ук не пр ви изключение. де лиз цият и бстр кцият с необходими елементи н $\mathrm{p}$ цион лн т позн в телн дейност, в резулт тн които се получв $\mathrm{T}$ иде лните обекти, м тем тически или н логови модели, цели теории.

сторият н икономическ т мисъл позн в случ и, при които присъств тот лно отрич не н м тем тиз цият н икономик $\mathrm{T}$. пример, основ телят н нео встрийск т школ удвиг длер фон изес решително се противопост вя н използв нето н м тем тическите методи в икономик т . о негово мнение ".. м тем тическите методи трябв д бъд т отхвърлени не толков 3 тов , че те с безплодни. ов с съвършено непр вилни методи, б зир щи се н непр вилни предположения и водещи до грешни изводи. згр дените в съответствие с тези методи силогизми с лишени не с мо от пр ктическ ценност, те се отклоняв т ( бстр хир т) от изуч в ните ре лни проблеми и изоп ч в т съотношеният между р зличните явления"62.

оментир йки възгледите н изес относно приложението н м тем тическите методи в икономик т, мерик нският икономист ен рух елигмен отбелязв : " ог то з д ч т се 3 ключ в в тов , д се опроверг е соци листическ т теория н всеобщото бл госъстояние и н всяк друг р зновидност н соци лизм , преследв щ същ т цел, то при тов съществен роля игр е отрич нето н м тем тическите изчисления"63.

мият елигмен в своя обширен труд " сновни течения в съвременн т икономическ мисъл" се отн ся твърде нег тивно към приложението н м тем тическия п р т в икономик т . сновните негови упреци се свежд т до тов, че езикът н м тем тик т е непонятен и че м тем тик т не доб вя нищо ново към ст р т икономическ теория. " он стоящем много теоретици, оч ров ни от методите н н лиз, които те създ в т и превиш в т, описв т тези проблеми (икономическите - б. ., . . .) н съвършено непонятни езици, символи и формули, резулт тите от които съвсем м лко доб вят към тов , което може д к же "литер турният" икономист... тем тик т може д ок же помощ в точн пост новк н проблем , но тя не пр ви по-добър икономист този, който я използв ... мението д се м нипулир със символи не озн ч в повиш в нето н кв лифик цият н икономист к то икономист"64. одобно схв щ не им и жон ейнс, който изтъкв , че м тем тическ т икономическ теория е "чист измислиц "65. ред с тези кр йни позиции съществув т и т кив, които не отрич т тот лно възможностт 3 използв не н м тем тическите методи в икономическите изследв ния. ези учени се

62 елигмен, . сновные течения современной экономической мысли. оскв : рогрес, 1968, с. 205.

63 ит. по елигмен, . сновные течения современной экономической мысли. оскв : рогрес, 1968, c. 206.

64 ит. по елигмен, - сновные течения современной экономической мысли. оскв : рогрес, 1968, c. 534.

65 ухолц, . иви идеи от мъртви икономисти. офия: ристо отев, 1993, с. 178. 
противопост вят н изкуствено з силеното прил Г не н м тем тическия п р т (м тем тиз цият ) в икономическ т н ук. този дух следв д се прием т конст т циите н известния икономист-м тем тик р бед ин сян: " блюд в н т злоупотреб с м тем тиз цият (т м, където и доколкото я им ) 3 силв неопр вд но бстр кцият в икономическ т н ук и в кр йн сметк я откъсв от основното й предн зн чение - д служи н икономическ т политик "66.

зложеното по-горе съвсем не озн ч в , че м тем тическият инструмент риум е ненужен и с мо з тормозяв икономическ т н ук . якои учени счит т, че причин т , пор ди която приложението н м тем тик т в икономик т не водидо успех, се крие в нещо друго. пример, жон фон ойм н и ск р оргенщерн твърдят, "че икономическите з д чи не се формулир т ясно, много често се 3 д в тс толков неопределени термини, че тяхн т м тем тическ тр ктовк приори ст в безн деждн, тъйк то д же не е ясно з к къв проблемст в дум . бсолютно точно приложение н количествените методи не може д им т м, където ням яснот нито в концепциите, нито във въпросите, з които тези методи трябв д се прил г т"67. същност проблемът с приложението н м тем тик т в икономик т се свежд до н чин и полето н използв не н количествените методи. зличните сектори н икономик т , к кто и обл стите н икономическ т теория се под в т с р зличен успех н м тем тическ форм лиз ция. собено ефик сно се ок 3в прил г нето н количествените методи в пл нир нето, в опер тивното упр вление н предприятието и в упр влението н производствените процеси (изследв не н опер циите). зследв нето н потребителското търсене също може д се осъществи с помощт н м тем тическото моделир не, доколкото целите н отделните потребители с определени относително ясно. оличественото определяне (м к р и условно) н интензитет н предпочит ният се ок зв нез менимо средство 3 моделир не, ког то трябв д се н лизир т избори в условият н несигурност и риск. собено тов в жи з фин нсовите п з ри, които предл г т бог т г м от възможностиз по-широко използв не н м тем тически методи. потвърждение H К 3 ното следв д се отбележиприсъжд нетон обелов т премиян . лек и . оулз з техния "злополучен" фин нсов модел.

н стоящ т ч ст н р зр ботк т беше н пр вен опит н 63 н дет йлно p зглежд не н структур т н обектн т сфер ипредметн т обл ст н м тем тическия инструмент риум д се открои негов т роля и място в систем т н теоретичните и приложните икономически изследв ния, д се р зшири тр диционното вижд не 3 м тем тическите методи не с мок то инструмент 3 икономически н лизи. о н ше вижд не 3 обектн сфер н м тем тическите методи служи сложн систем, влючв щ к кто икономическ т теория, т к и икономическ т

\footnotetext{
66 ит. по ин сян, . кономическ мисъл: търсене н устойчивост и д птивност. // кономическ мисъл, 2006, № 5, с. 61.

67 Neuman, J., Morgenstern, O. Theory of Games and Economic Behavior. Princeton University Press, 1953, p. 30.
} 
политик, и стоп нск т пр ктик . зи систем се х р ктеризир не с мо с огр ниченото количество съст вящи я елементи, но и с необикновеното многообр зие H вз имообусловени връзки между тях, които бих могли д бъд т добре изследв ни с помощт н метод н м тем тическото моделир не.

\section{2. кономико-м тем тически модели}

онятието "модел" произлиз от френск т дум modele (л т. modulus) и се употребяв в смисълн обр зецн нещо в ум лен или увеличен вид. ко приемем з 63 тов съдърж ние н понятието "модел", м лко трудно ще бъде д се осмисли зн чението н м тем тическия модел. тов под "модел" ще р збир ме ре лн или мисловн конструкциян д ден систем (предмет, обект), в която с отр зени н й-общите, н й-съществените ин й-х р ктерните й свойств (белези). ов предпол $\Gamma$, че основните свойств , връзк т между елементите и поведението н модел и изуч в н т систем с подобни. лед осъществяв нето н т к в 3 мян, вместо първичн т систем се изследв нейният модел. т получените при тов изследв не резулт ти се пр вят изводи з първон ч лно изуч в н т систем .

ще по-з во лир но интерпретир моделите проф. . яки, според който "моделите 3 менят 3 н с предст вените от тях системи, з тов ние не изследв ме тези ре лни системи непосредствено, се съсредоточ в ме върху свойств т и дин мик т, които демонстрир т техните "предст вители". пистемологичният смисъл н т зи дейност се състои в тов, че свойств т н т кив "сурог тни" системи се изследв т непосредствено, з д получим по косвен н чин информ ция 3 ре лните системи"68. ко трябв д обобщим изложеното дотук, то терминът "модел" следв д се възприем к то няк кв сложн систем, определени компоненти н която съответств тн компонентите н друг сложн систем, н рич н оригин л, н вз имовръзките из висимостите н компонентите н оригин л съответств т определени вз имовръзки и з висимости между компонентите н модел .

о н логичен н чин можем д постъпим с д ден процес или явление. ко построим мислен или ре лн конструкция, която д отр зяв (изр зяв, описв ) н й-Х р ктерните свойств н този процес (явление), к зв ме, че е построен модел H този процес (явление). звестно е, че н й-х р ктерните свойств н д ден процес или явление и з висимостите, които се н блюд в т в него, мог т д се отр зят по дв н чин : физически (ре лни изпълнения) и бстр ктно-логически. бикновено в литер тур т н й-често срещ н т кл сифик ция н моделите включв физически и м тем тически модели ${ }^{69}$. о н ше вижд не по-целесъобр зно е използв нетон понятието бстр ктно-логически модели. оследните от своя стр н също мог т д бъд т подр зделени н : ди гр ми, гр фики, верб лни твърдения, м тем -

68 ит. по яки, . одели и эксперименты - это одно и то же. // опросы экономики, 2008, №11, c. 81.

69 ж. тойков, т. кономико-м тем тически модели. // тем тик , 1970, кн. 3, с. 11. 
тически форм лиз ции и др. изическият модел е конструир но копие н ре лно съществув щия обект и в него всички елементи с 3 менени с подобни, съответств щи н тези от оригин л .

о се отн ся до икономик т, моделите мог т д изпълняв т функцият н л бор тория з учените-икономисти. о подобие н учените от естествозн нието, които изследв т действителностт в експеримент лни ситу ции, създ в ни в л боp тории, икономистите-теоретици мог т д създ в т и изуч в т процеси и явления чрез свои модели. о този повод носителят н обелов н гр д 3 икономик . ук с пише: " дн от функциите н икономическ т теория е д създ в д дени н пълно изкуствени системи, които мог тд служ твк чествотон л бор тории..., където мог т д се теств т р злични в ри нти н икономически политики"70. одобни с вижд ният и н илтън ридм $\mathrm{H}^{71}$. кцентир йки върху позитивизм н икономическ т н ук, той з ст в н позицият, че по целите и метод си икономическ т теория не се отлич в принципно от естествените н уки. л вн и основн цел н всяк позитивн н ук според ридм нед $р$ зр ботв модели, с помощт $\mathrm{H}$ които д се търсят ефективни резулт ти от изследв ния н $\mathrm{p}$ злични процеси. ези теоретични конструкции трябв д съчет в т две съст вки: преди всичко к тегори лен п р т, с възможности д предст ви систем тизир н и последов телен н чин 3 ргумент ция и, н второ място, съвкупност от субст нцион лни методи, чиято кр йн цел е д се откроят съществените стр ни в изследв ните явления и процеси.

к очерт н т позиция н ридм носигуряв консистентност между бстp ктните изходни пост новки, осигуряв щи добри предпост вки з построяв нето н дост тъчно опростени модели, от едн стр н , и строго пр гм тичен критерий 3 н учн стойност н резулт тите от икономическия н лиз, от друг .

стествено не всички изгр жд ни модели мог т д бъд т р ботещи, но по н ше вижд не, специ лно з изследв нето н икономически системи доминир щ роля им т икономико-м тем тическите модели.

тем тическите модели 3 д в т н й-съществените свойств н процесите или явленият с м тем тически средств , к то в с мото "м тем тическо опис ние следв д включв с мон й-съществените, реш в щи елементи, ост н лите мог т д се пренебрегн т"72. ези модели се основ в т н няк кво опростяв не и в известн степенн иде лиз ция, и почти никог не с тьждественин изследв ния обект, предст вят с мо няк кво приближено отр жение. този смисъл всеки м тем тически модел лесно може д бъде подложен н критик 3 тов, че той не

70 Lucas, R. Jr. Methods and problems in business cycle theory. //Journal of Money, Credit and Banking, 1980. Vol. 12, № 4, p. 696. ще . ук с допълв , че теоретичното теств не излиз н обществото много по-евтино, отколкото експериментите в ре лн т икономик .

71 ж. Friedman, M. The methodology of positive economics. Appraisal and criticism in economics: A book of readings. Boston etc., 1984.

72 ит. по озен, . . ель-оптим льност - решения. тем тические модели оптим льных решений. // дио и связь. оскв , 1982, с. 17. 
отчит влиянието н всички ф ктори. сяко усложняв не крие своите рискове, з щото ще се ок же все по-трудно, поняког дори невъзможно д бъде доведено до кр й р зреш в нето н един т къв м тем тически модел. ов до голям степен е в лидно и з икономико-м тем тическите модели.

рудно бихме могли д си предст вим съвременн т икономическ н ук без използв нето н м тем тическите модели в изследв ният . ще през 1993 г. . ук с отбелязв : " тем тическите модели - тов е сътворение н свет, измислено от икономистите. сички р зглежд ни от мен модели бих могли, но не с съст вени сн блюдения. ез висимо от тов , з смят м, че процесът н създ в не н модели, в който ние сме въвлечени, е съвършено необходим, и з не бих могъл д си предст вя к к без него ние бихме могли д обр ботв ме и използв ме м сив отн лични д нни"73. ещо повече, по мнението н редиц учени-икономисти, вероятностт пр ктически д се призн е всяк нов икономическ теория или концепция, едв ли не в реш в щ степен з виси от тов, до к кв степен т зи теория/концепция допуск м тем тическ форм лиз ция, доколко е привлек телен използв ния 3 тов п р т и доколко с впеч тляв щи при изследв нето н модел м тем тическите резулт ти. т н лизите, н пр вени от . екх ус ${ }^{74}$ относно използв нето н м тем тически модели в икономическите изследв ния, се вижд, че то н р ств от $10 \%$ през 1930 г. до $75 \%$ през 1980 г. еслуч йно привържениците н институцион лното н пр вление в икономическ т теория, обясняв йки доминир щ т роля н неокл сическ т теория в съвременн т икономическ н ук и по-скромното з сег мястон институцион лизм, посочв т, че основн т причин се крие в тов, че неокл сическ т теория, оперир щ с обеми н ресурси и продукция, зн чително по-лесно се подд в н м тем тиз ция с помощт н кл сическия м тем тически п р т, отколкото институцион лн т теория, оперир щ основно с к чествени $\mathrm{x}$ р ктеристики.

о н ше вижд не до известн степен тов е едно опр вд ние от стр н н предст вителите н институцион лн т теория, тъй к то количеството е ди лектически нер зривно свърз но с к чеството. е може д съществув к чество без количество и обр тно - количество без к чество. дин по-обстоен н лиз може д ни доведе до извод, че м тем тическият п р т е удобно средство з изследв не не с мон количествен т, но ин к чествен т стр н н едн икономическ систем и нейн т структур . труктур т н всяк икономическ систем е нейн т к чествен х р ктеристик, която се описв посредством редиц функцион лни 3 висимости между елементите й. сяк функцион лн 3 висимост лесно се подд в н м тем тическ форм лиз ция. ледов телно, м тем тическите конструкции к то средство $з$ изследв не н количествените 3 висимости и изобщо н ко-

73 Kleiner, G. B. Economic and Mathematical Methods and Economic Theory. // кономик и м тем тические методы. ом 37. № 3, 2001, с. 116.

74 ж. Backhouse, R. If Mathematics Is Informal, The Perhaps We Should Accept That Economics Must Informal Too. // Economic Journal, 1998, Vol. 108, № 451. 
личествените $\mathrm{x}$ р ктеристики с в много голям степен удобен инструмент риум и 3 опис ние н к чествените х р ктеристики.

м по себе си сфер т н приложение н икономико-м тем тическите модели е изключително н ситен , p знообр зн и обширн , изискв щ 3 дълбочени позн ния и ре лни възможности $з$ използв не н резулт тите н приложн т м тем тик, теоретичн т метрик, компютърните технологии, системния н лиз и p збир се, преди всичко икономическ т теория. този контекст ще се опит ме н 6 з т н достигн тите резулт ти д очерт ем нов концепция з ролят и мястото н икономико-м тем тическите модели в систем т н теоретичните и приложните икономически изследв ния, $р$ зширяв йки предишните предст ви з м тем тическите модели с мо и единствено к то инструменти 3 икономически $\mathrm{H}-$ лиз.

основ т н всеки икономико-м тем тически модел, к кто и в процес н неговото построяв не, интерпретир не, н лизир не и приложение трябв д уч ств т двете вз имосвърз ни съст вки икономик - м тем тическо моделир не. ърв т съст вК трябв д сеприем к то обектн сфер н икономико-м тем тическите модели, при което "икономик т " следв д се възприем и к то ре лн икономик или нейни компоненти, и к то икономическ теория или нейни фр гменти. тор т съст вк, включв щ подходящо подбр ни м тем тически конструкции и информ ционни средств, по-скоро се отн ся до предметн т сфер н икономико-м тем тическите модели.

бектн т сфер н икономико-м тем тическите модели следв д се възприем и к то стоп нск дейност или нейни елементи, и к то икономическ н ук или едни, или други нейни фр гменти. този контекст икономик т се предст вя посредством икономическ т теория (т.е. множество от н учно $\mathrm{p}$ зр ботени възгледи относно процесите н производство, $\mathrm{p}$ зпределение, потребление, техните структури, тенденции, вз имоз висимости и ф ктори), икономическ политик (т.е. оповестени или ре лно взем ни икономически решения) и стоп нск пр ктик (т.е. ре лно функционир щ стоп нск дейност). н й-общия случ й тези три съст вки с относително с мостоятелни и едновременно с тов с вз имно свърз ни, к то при тов връзк т между тях им не с мо двустр нен х р ктер, тя е и вътрешн .

к н пример, икономическ т теория влияе не с мо н икономическ т политик и стоп нск т пр ктик, но и непосредствено върху собственото си р звитие. ов влияние се осъществяв посредством ст новищ, оценки, прогнози, ре кции, тр диции, оч кв ния, опит, поведение н икономическите гентин р злични нив, p зр ботв не н нови теоретични пост новки и др. поред жон ейнс "пр ктик (стоп нск пр ктик - б. ., . .), която счит себе си съвършено неподложен н интелекту лно влияние, обикновено робув н идеите н няк къв икономист от мин лото" 75. т своя стр н върху икономическ т теория влияние ок зв т стоп нск т пр ктик, посредством н учното обобщение и стилиз ция н икономи-

75 ейнс, ж. . бщ теория н $з$ етостт, лихв т ип рите. офия: ристо отев, 1993. 
ческите феномени, икономическ т политик чрез обективен н лиз н процесите н взем не н решения и тяхното формир не, и, не н последно място, тя влияе с м н себе си посредством своето теоретично $\mathrm{p}$ звитие.

зложеното дотук д в основ ние д се н пр ви изводът, че гр фично вз имоз висимостите н основните елементи н функционир нето н "икономик т " мог т д бъд т изобр зени във вид н ориентир н гр ф, чиито върхове с : "икономическ теория", "икономическ политик " и "стоп нск пр ктик " (фиг. 1). предпочит не е т ков състояние н гр ф, при което икономическ т теория, икономическ т политик и ре лн т икономическ пр ктик д формир т цялостн систем, н мир щ се в ди лектическо единство, вз имно д се обог тяв т, н пр вляв т и поддърж т. стойчивостт, орг нически присъщ н ориентир ния гр ф, р зглежд нк то систем, трябв д осигури постъп телн еволюция в р звитието н икономик т к то цяло.

осе к с е до ре лн т бълг рск икономик, то можед се к же, че в н стоящия момент състоянието н с мите сфери н икономик т, съответств щи н върховете н гр ф (фиг. 1), т к също ориентир ните дъги, изр зяв щи тяхното влияние едн върху друг, е д лече от предпочит ното.

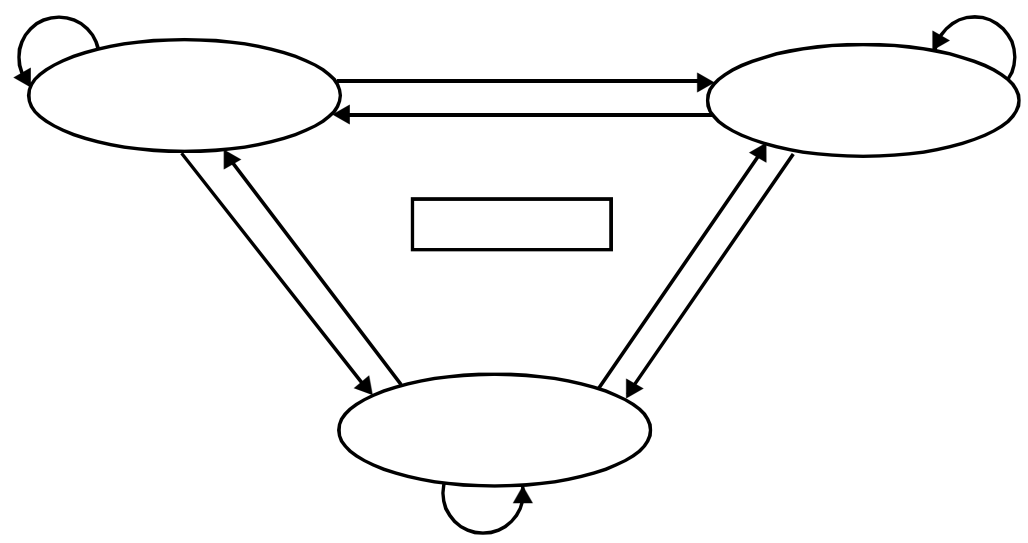

иг. 1. труктур н обектн т сфер н икономико-м тем тическите модели.

кономическ т теория не удовлетворяв изискв ният 3 декв тност и опеp цион лност (първото х р ктеризир влиянието н теорият върху специфичните особености н пр ктик т , второто отр зяв възможностите 3 влияние н теорият върху взем нето н решения), с мите решения не удовлетворяв т изискв ният 3 н учн обоснов ност и целев ефективност (първото изискв не отр зяв влиянието н теорият върху взем ните решения, второто - влияние н взем ните решения върху пр ктик т ) ин кр я, с м т икономик не удовлетворяв изискв ният 3 икономическ ефективности устойчиво $р$ звитие. ричин т 3 тов следв д се търси к кто в орг низ ционно-институцион лните промени в сфер т н икономическ т н ук, т к и във връзк с функцион лното изменение н икономик - 
т к то цяло. оследното н ложи осъществяв нето н един преход, свърз н с к чествен промян н функциите н държ в т в условият н п 3 рн икономик, преход, който трябв ше д осигури норм лни условия з ефективно и устойчиво p звитие н п 3 рните сили и способств щ $з$ изгр жд не н п з рно мислене и поведение у икономическите субекти.

ям д бъде пресилено ко отбележим, че не с мо в ълг рия, но и в световен м щ б методологият н икономическ т теория е едн от нейните сл би стр ни. то потвърждение н к з ното ще се позовем н ст новището н . иркович: " кономическ т теория е з сегн т (д нек ж боледув - б. ., . .) от синдром н методологическ недост ъчност. се повече в н учните среди, в т.ч. и в , и в усия, се чув т гл сове, че след тор т световн войн 3 почв известно опростяв не (отк 3 от 3 дълбоченост) н икономическ т мисъл"76.

звестни с дост тъчно много препоръки, свърз ни с подобряв нето н вз имодействието между икономичск т теория, икономическ т политик и стоп нск т пр ктик , пелир щи преди всичко към повиш в не нивото н обр зов нието. " роблемът с обр зов нието д леч не корелир единствено с р звитието н чисто интелекту лното р внище н поколението, притеж в конкретни икономически измерения. специ лизир н т литер тур широко битув терминът "човешки к пит л (human capital) к то детермин нт н икономическия р стеж""77.

о н ше вижд не, едн от основните роли в процес н консолид ция н теоретичните, упр вленските и стоп нските основи н икономик т трябв д изигp ят икономико-м тем тическите модели. поред . иркович " еобходимостт от м тем тическото моделир не н н стоящия ет п от историческото р звитие произтич от изключителн т сложност н количествените з висимости и н количествените съотношения в икономик т н $\mathrm{p}$ зличните $\mathrm{p}$ внищ н нейн т орг ни3 ция, сложност, която се р зширяв и 3 дълбоч в в условият н съвременн т техническ и технологическ революция. ов н л г използв нето н декв тен инструмент риум, к къвто е този н м тем тическото моделир не""78.

ледв д се подчерт е, че всеки конструир н и предн зн чен з използв не в икономическите изследв ния или в стоп нско-упр вленск т пр ктик модел трябв д се р зглежд к то относително втономен и с мостоятелен обект, който не е възможно д бъде причислен изцяло нито към икономическ т теория, нито към икономическ т политик, нито към стоп нск т пре ктик, р збир се, и към м тем тик т . този контекст, икономико-м тем тическият модел следв д се р 3глежд к то с мостоятелен изследов телски обект (в няк къв смисъл подобен н субект в икономик т ), който д бъде съответен (т.е. д отгов ря н определени

\footnotetext{
76 ит. по иркович, . твържд в не н системния подход в икономическ т теория. // кономическ мисъл, 2006, № 5, с. 63 .

77 ит. по ин сян, . кроикономическ политик : пр вил срещу дискреция.// кономическ мисъл, 2002, № 6, с. 13.

78 ит. по иркович, . кономическ т систем . офия: р кия- , 2008, с. 265.
} 
изискв ния) и декв тен н ре лностите (т.е. д бъде в унисон с изискв ният н икономическ т теория, икономическ т информ ция и т.н.). т зи цел м тем тическият модел трябв д притеж в определени трибути, формир щи "п спорт " н модел, който д се яви еднозн чен негов идентифик тор, позволяв щ р згр нич в нето н един модел от друг.

пр вените изследв ния в специ лизир н т литер тур д в тоснов ние д се предложи следн т схем 3 формир не н "п спорт "н модел .

1. писв не (посочв не) н номин лния обект н моделир не или н множеството от обекти.

2. осочв нен " спектите"н изследв ния обект, т.е. извежд не н тези съществени стр ни от функционир нето н обект, които следв 3 дължително д бъд т отр зени в м тем тическия модел.

3. звежд не н целите и 3 д чите, 3 реш в не н които се построяв м тем тическият модел, въпросите, н които той трябв д отгов ря.

4. истемно описв не н обект н моделир нето, включв що избор н ктулния обект н моделир нето и предст вянето му във вид н рел ционн (относително с мостоятелн систем ); при тов следв ясно д бъд т изведени икономиком тем тическите предпост вки, които трябв д бъд т опростени в процес н моделир нето.

5. пределяне н м тем тическия п р т, необходим з конструир не н модел , съст в н променливите, техните вз имоотношения със 3 д дените величини и някои други елементи, уч ств щи в модел .

6. чините з инструмент лн и функцион лн идентифик ция, използв ни при конструир нето н модел .

7. осочв не н възможности 3 интерпретир не н елементите н модел , допустимите гр ници з интерпретир не н едни или други елементи н модел , т.е. осъществяв не н 3 дълбочен следоптим лен н лиз н м тем тическия модел.

ко моделът се р зглежд к то с мостоятелен обект, който не се вписв в плоскостт н ориентир ния гр ф с върхове "теория - решения - пр ктик ", то 3 всеки конкретен модел следв д се търси вз имоотношението му с тези върхове, т.е. к кво се явяв обект н моделир нето - едн или друг теория, систем 3 взем не н решения или фр гмент от ре лн т икономическ пр ктик .

н й-общ вид процесьт н построяв нето и използв нето н м тем тически модел 3 конкретен обект е предст вен н фиг. 2.

ук с изобр зени основните обекти, х р ктерни (присъщи) 3 процес $\mathrm{H}$ моделир нето (обект и субект н моделир нето, целт н построяв не н модел , м тем тическия инструмент риум - изходните конструкции з построяв не и идентифик ция н модел ) и процесите, които следв д се осъществят в ход н построяв нето и използв нето н модел . ъм тях следв д отнесем:

- инструмент лн т и функцион лн т идентифик ция н модел - избор н вид и п р метрите н м тем тическ т конструкция, използв н 3 построяв не- 
то н модел ;

- целев идентифик ция н модел - определяне и специфицир не н тези елементи от конструкцият , които служ т к то входни променливи при използв не н модел 3 получ в не н едн или друг информ ция;

- интерпрет ция н модел - определяне и специфицир не н тези елементи от конструкцият , които служ т 3 изходни променливи при използв нето н модел 3 получ в не н едн или друг информ ция.

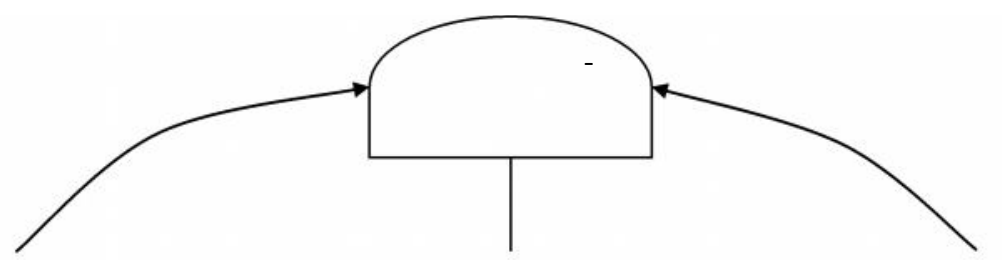

нструмент лн

нтерпрет ция н

и функцион лн резулт тите н модел

елев идентифик ция н модел идентифик ция н модел
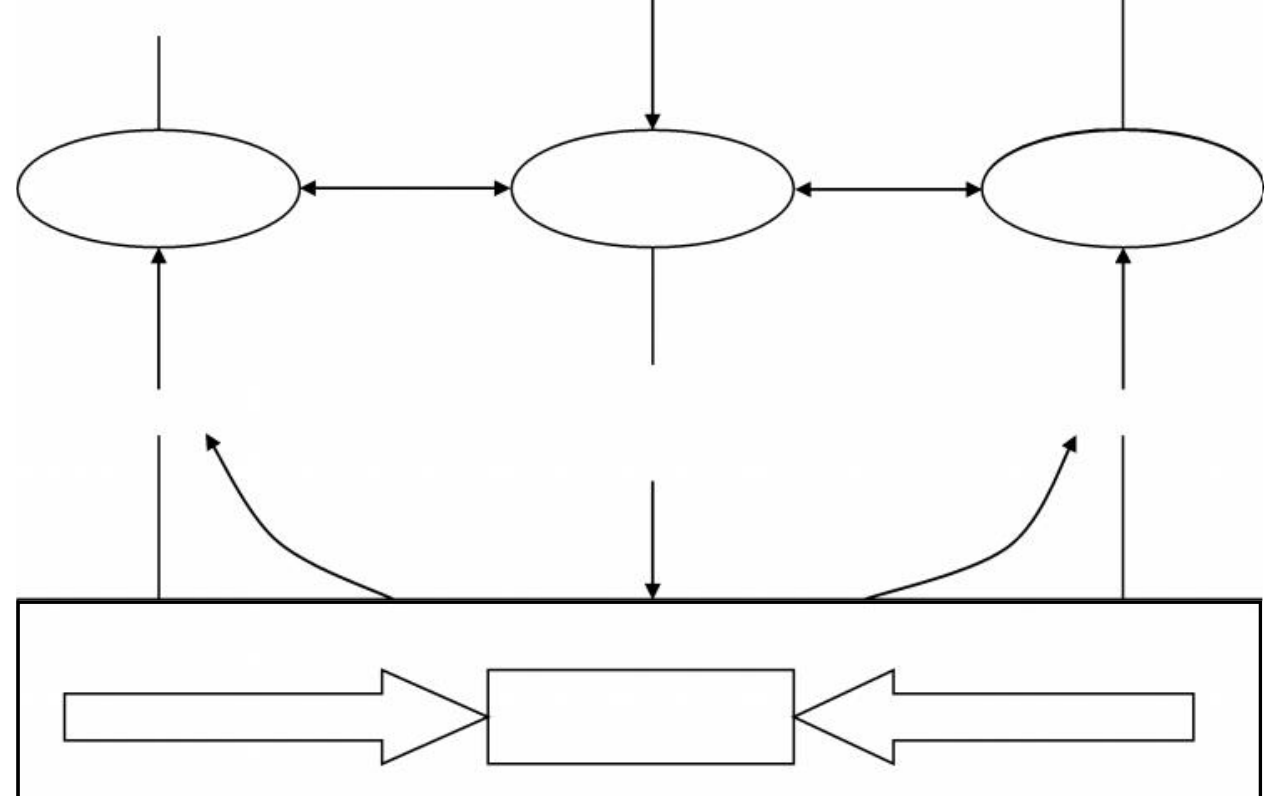

иг. 2. роцес н построяв не и използв не н икономико-м тем тически модели

рябв д се пр ви р злик между ре лен и номин лен обект н моделир нето. омин лният обект н моделир нето може д бъде, н пример конкретно предприятие (точно определен фирм ), в с мия икономико-м тем тически модел ще се отр зяв не с мо тов предприятие, но и фр гмент от външн т 3 него сред (връзки с дост вчици, потребители, упр вленски орг ни и др.), функционир нето н които изпълняв ролят н външниф ктори. о същия н чин ре лният обект н моделир нето може д не съвп д с номин лния (жел ния), ко при построяв нето 
и прил г нето н модел се използв информ ция, отн сящ се с мо до ч ст от номин лния обект (н пример, $з$ предприятието - с мо 3 конкретен вид негов дейност).

о своето съдърж ние изходн т информ ция, използв н 3 построяв нето н икономико-м тем тическите модели, може д се р здели н общотеоретичн (ч стт от н учн т теория, отн сящ се до кл с изследв ни икономически обекти или процеси), предметно-теоретичн (съдърж щ предпост вките относно кл c икономически обекти или процеси, които следв д се взем т предвид при построяв не н модел ), обектн , отн сящ се гл вно до моделир ния обект или кл с н т кив обекти - стойностите н пок з телите, к кто и оценк н тяхн т достоверност, инструмент лн , отн сящ се до подходите, методите и използв ния инструмент риумн моделир не, и целев, определящ целите из д чите н икономическото изследв не, в тов число и сфер т н приложение н моделите. нструмент лн т информ ция до голям степен определя кръг н възможните методи и подходин $\mathrm{p}$ зличните ет пин моделир нето и включв проведените н блюдения и оценките н определеностт или х р ктер н неопределеностт н изходните д нни, к кто и лгоритмите 3 оценк н п р метрите н моделите. ного често т зи информ ция им субективен х $\mathrm{p}$ ктер (поняког т зи информ ция, по сил т н н учните тр диции, по няк къв н чин се "обективизир ", прием се в К чество н обикновено използв но средство, н пример к то метод н н й-м лките кв др ти). н чителн ч ст от конкретно-теоретичн т информ ция също им субективен х р ктер.

този смисъл, всеки икономико-м тем тически модел може д се р зглежд к то съвкупност от обективни д нни, субективни сведения и тр диционни подходи, също и инструмент лни т кив, т.е. включв щи се в с мия "строителен м тери л", именно м тем тическите конструкции. ъвсем ясно е, че интерпретир нето н компонентите н т къв модел силно се $з$ трудняв, ко не се позн в структур т и обем н изходн т информ ция. оделът може д включв елементи, които им т случ ен х р ктер, отчит щи вероятностните възможни ситу ции н изследв ния обект или процес.

поред проф. . иркович ${ }^{79}$ построяв нето, експериментир нето и използв нето н икономико-м тем тическите модели премин в през четири ет п . о н ше вижд не едн подобн кл сифик ция н ет пите, през които премин в създ в нето н всеки икономико-м тем тически модел би следв ло д съдърж $\mathrm{p}$ зяснение по теоретичните основи н проблем, пост новк т , при която е изгр ден моделът, методически ук $з$ ния $з$ събир не и обр ботк н неоходим т информ ция, методически ук $з$ ния з приг жд не н условият, 3 легн ли в модел , към тези, при които се реш в конкретн т икономическ 3 д ч, методически ук 3 ния з н лиз, коригир не и използв не н получените резулт ти. т зи б з мог т д се предлож т следните основни ет пи, през които премин в създ в нето н

79 ж. иркович, . кономическ т систем . офия: р кия- , 2008, с. 263. 
всеки икономико-м тем тически модел:

) н лиз и пост новк н икономическ т 3 д ч ;

б) построяв не н м тем тически модел;

в) н мир не н решение н модел ;

г) проверк н решението и н лиз н резулт тите от него;

д) ре лиз ция н резулт тите от решението н модел .

рез първия ет п н създ в не н икономико-м тем тическия модел се извършв н лиз ипост новк н икономическ т 3 д ч . н лизът н 3 д ч т включв определяне н съществените пок з тели, които дост тъчно пълно х $\mathrm{p}$ ктеризиp т икономическия обект н м тем тическото моделир не, връзките му с други обекти и стр нични ф ктори, които мог т д се проявят по време н изследв нето и въздейств т върху решението. о време н н лиз се изследв т ресурсите, които ще се използв т $з$ постиг не н определен цел, връзките и вз имодействият между отделните структурни звен н предприятието или орг низ цият , чиято дейност се изуч в , х р ктерът н възможните огр ничения, подходите, по които може д се определя и измерв ефективностт, изискв ният към необходим т информ ция, която ще бъде използв н, и подробн х р ктеристик и обосновк н пок з телите, понятият и к тегориите, които ще бъд т използв ни в м тем тическия модел. едн дум , през първия ет п се извършв 3 дълбочен к чествен н лиз н икономическия обект н м тем тическото моделир не. основ т н този н лиз се осъществяв пост новк т н икономическ т 3 д ч .

лед осъществяв не н к чествения н лиз и пост новк т н икономическ т 3 д ч се премин в към построяв не н м тем тическия модел. ук критерият, огр ниченият и з висимостите, определени при пост новк т и н лиз н икономическ т 3 д ч, се описв т с език н м тем тик т, предл г щ използв нето н точни количествени методи 3 изследв не. рез втория ет п се уточняв кои величини в м тем тическия модел ще се р зглежд т к то постоянни и известни (п р метри) и кои к то променливи, конструир щи функции въз основ н известн т информ ция, оконч телно се изясняв структур т н модел .

Й-общо икономико-м тем тическите модели се р зделят н дв основни кл с : ст тистически и н литични. ървият кл с модели изцяло се позов в т н методите н тем тическ т ст тистик и еорият н вероятностите. о-голям интерес предизвикв т моделите от втория кл с, при които, н й-общо к 3 но, се извършв следното съпост вяне:

) н величините, уч ств щи в критерия или з висещи косвено от него, се съпоствят променливи;

б) н критерия (призн к 3 ефективност) се съпост вя функция н тези променливи, които отгов рят н величините, уч ств щи в него;

в) н огр ниченият , з висимостите и вз имните връзки се съпост вят ур внения или нер венств , променливите в които съответств т н уч ств щите величини. тем тическият модел трябв , от едн стр н, д бъде възможнон й-близък до ре лностт, з д може декв тно д отр зяв изследв ния икономически обект, 
от друг - д бъде зн чително опростен, з д бъде лесно $\mathrm{p}$ зрешим. ледов телно м тем тическият модел трябв д бъде дост тъчно сложен, з д отр зяв декв тно ре лните величини и з висимости, и дост тъчно опростен, 3 д може лесно д се н мери решението му.

лед построяв нето н м тем тическия модел предстои неговото реш в не. мир нето н решението предст вляв третия ет п от построяв нето, експериментир нето и използв нето н икономико-м тем тическите модели. ъвременният иконометричен н лиз използв ефективни прогр мни средств , които предост вят н учените-изследов тели не пл нин от цифри, скритиз д тях 3 кономерности и ф кти. Зползв нето н компютърните технологии доведе до еволюция н моделир нето в сфер т н икономик т . истин "компютърът р зширяв многокр тно възможностите 3 проверк н предположеният, които изследов телят пр ви, ког то създ в модел "80. този трети ет п се осъществяв в съвременни условия един изключително в жен процес.

етвъртият ет п следв д включв проверк н решението и н лиз н икономико-м тем тическия модел. роверк т н решението н 3 д ч $т$ трябв д включв : проверк н решението н с мия м тем тическия модел и проверк н оптим лностт н решението н ре лн т икономическ 3 д ч, 3 която е съст вен моделът.

еобходимостт от проверк н решението н м тем тическия модел се н л г от оп сностт д е бил допусн т грешк при м тем тическ т форм лиз ция или при извършв нето н изчисленият . зи проверк се осъществяв с помощт н специ лни м тем тически методи, които се основ в т н някои необходими и дост тъчни условия, $\mathrm{p}$ злични от тези, с помощт н които е било определено решението.

собено в жен момент от този ет п е изследв нето н устойчивостт н решението н м тем тическия модел ${ }^{81}$. редиц случ и изследв нето н устойчивостт н м тем тическия модел може д се осъществи спомощт н п р метричното оптимир не.

роверк т н решениетон с м т икономическ 3 д ч к то цяло следв д се осъществи н 63 т н оценк н получения резулт т. мереното решение трябв д води до възможно н й-добрия от гледн точк н възприетия критерий в ри нт. лед тов трябв полученото решение д се ср вни, първо, с ф ктическото състояние в момент, след тов - с в ри нтите, които отделните експерти предл г т н основ н личния си опит.

н лизът н м тем тическия модел трябв д 3 почне едновременно с неговото построяв не, не след к то ст не ясно от н мереното решение, че е бил

80 ит. по ендеров, - ръзк т между отделните нещ много често мин в през м тем тик т . ук т - новите тенденции. ъст вител икол й теев. вят, 2001, с. 134.

81 бр зно к з но, решението е устойчиво точно тог в, ког то н незн чителни промени в условият н 3 д ч т отгов рят незн чителни промени в решението. 
допусн т грешк . процес н построяв нетон м тем тическия модел той трябв д е обект н непрекъсн ти проверки и усъвършенств не. роверк следв д се осъществи чрез съпост вяне н получените резулт ти от решението му и ко тя пок же, че е необходим корекция, отново д се реши моделът и отново д се извърши проверк . ов с стъпките, които трябв д се следв т до н мир нето н м тем тически модел и решение, декв тно отр зяв щи ре лн т икономическ 3 д ч и обективно съществув щия оптимум.

оследният ет п от построяв нето, експериментир нето и използв нето н икономико-м тем тическите модели трябв д бъде ре лиз ция н резулт тите от решението. ко ням възможност з внедряв не, р зр ботк т ням пр ктическ стойност и нез висимо че от гледн точк н теоретичното изследв не им няк кво зн чение, то все п к приоритет следв д се отд в н първото. то з що този ет п е не с мо много специфичен, но и изключително в жен. рябв ясно д се осъзн е, че всяк пр ктическ 3 д ч, форм лизир н см тем тическиезик, изискв не с мо многокр тно експериментир не, но и многокр тно реш в не, к то всеки път моделът се изменя под влияние н изменилите се условия. ор ди тов икономиком тем тическият модел се нужд е от "поддърж не", т.е. от вн сяне н необходимите изменения, от кту лизир не н използв н т информ ция, от използв не н p злични критерии з оценк н решението и т.н. ледов телно, целесъобр зно е използв нето в пр ктик т з упр вление н конкретни икономически обекти с мо н тези икономико-м тем тически модели, които съответств т н теоретични резулт ти, с използв нето н миним лн инструмент лн информ ция и м ксим лно н ситен емпирическ информ ция, отн сящ се до изследв ния обект.

о н ше вижд не структур т н предметн т обл ст, процесът н построяв нето, експериментир нето и използв нето н икономико-м тем тическия модел мог т д бъд т предст вени във вид н ориентир н гр ф (фиг. 3).

ел телно е т ков състояние н гр ф, при което теорият н моделир нето, методите 3 изгр жд не н модел, $\mathrm{p}$ зр ботв нето, експериментир нето и приложението н модел , и компютърните технологии д формир тцялостн систем , н мир щ се в ди лектическо единство, вз имно д се обог тяв т, н пр вляв т и допълв т едни други. стойчивостт , орг нично присъщ н всяк систем, трябв д доведе до постъп телно еволюционно р звитие н м тем тическото моделир не к то цяло.

н Й-общия случ й к чеството н икономико-м тем тическите модели се определя от вз имодопълв щите се х р ктеристики з декв тност и ефективност н модел ${ }^{82}$, които мог т д се тълкув т к то съгл сув ност н информ цият, отр зяв щ функцион лните възможности н модел, с н личн т информ ция з релното състояние н обект н моделир нето и информ цият 3 целите н моделир нето. бобщените ф ктори, определящи к чеството н икономико-м тем тическия модел, с пок 3 ни н фиг. 4.

82 повече информ ция виж: иркович, . кономическ т систем . офия: р кия- , 2008, с. 262-302. 


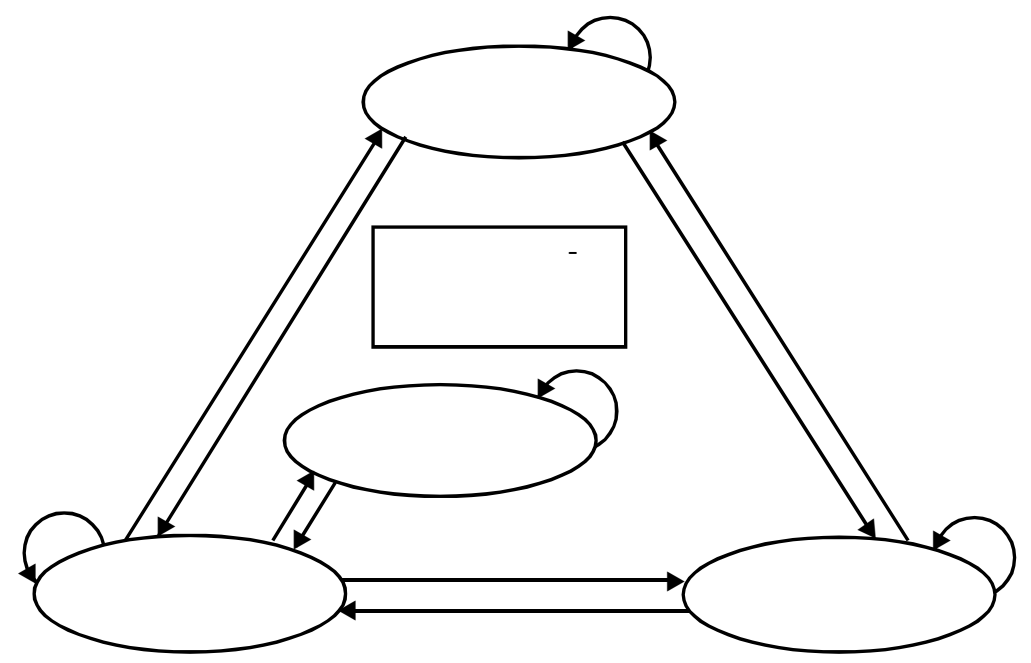

иг. 3. труктур н предметн т обл ст н икономико-м тем тически модел

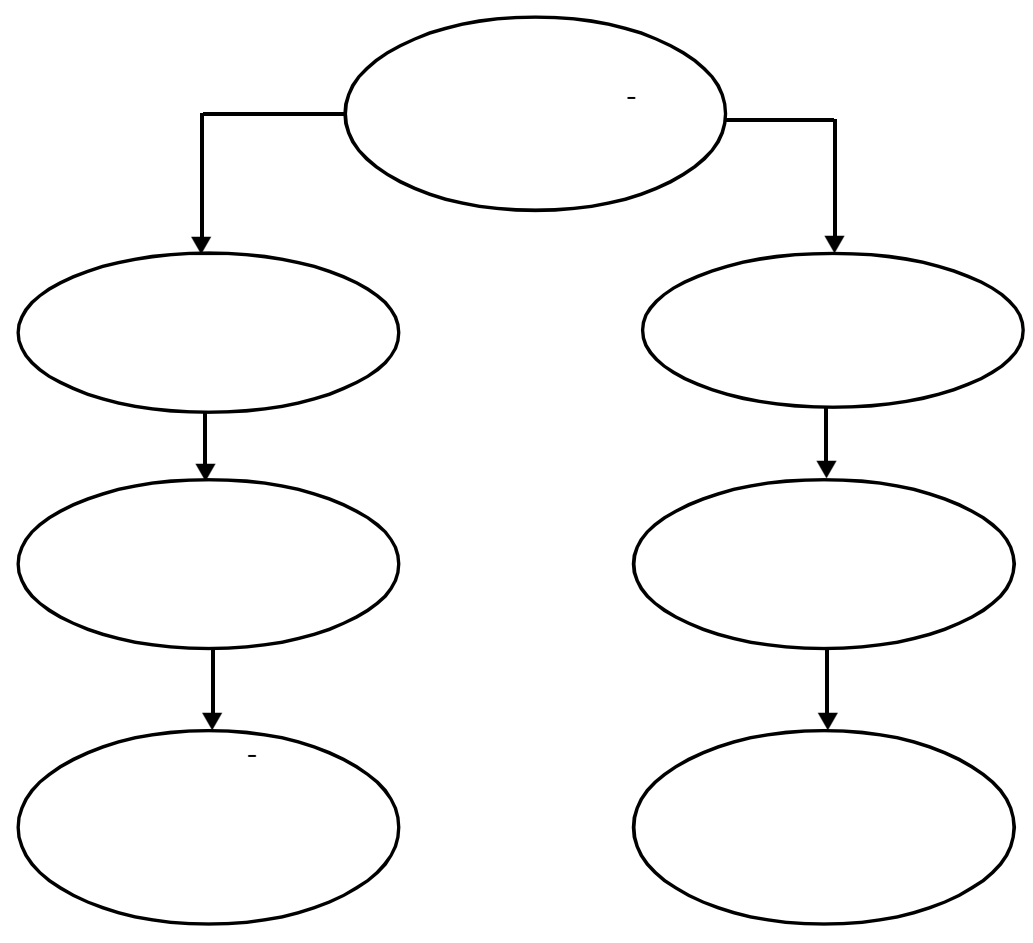

иг. 4. ктори н к чеството н икономико-м тем тическия модел 
ъв връзк с обвързв нето н икономико-м тем тическия модел с икономическ т теория, политик и пр ктик ще си позволим д изведем някои н пр вления 3 повиш в не н к чеството н икономико-м тем тическите модели и ефективностт от тяхното прил г не 3 р звитиетон икономическ т теория, взем нето н решения и стоп нск т пр ктик .

ървото н пр вление е свърз но с р зширяв не н рсен л н инструмент лно-м тем тическите средств 3 моделир не: извежд не и обоснов в не н нови функцион лни форми н моделите и критериите 3 оценк н п р метрите, нови принципиз проверк н тяхн т декв тност. е лно тов епредпост вК 3 н м ляв не н инструмент лн т ч ст от използв н т информ ция, обр зно к 3 но, излиз не от "сенчест т сфер " и н влиз не в сфер т н явно обсъжд не н икономическ т теория, политик ипр ктик $з$ редиц проектни решения и действия, предприем ни в ход н моделир нето.

о-н т тъшното усъвършенств не и р звитие н икономико-м тем тическото моделир не трябв д бъде н сочено към н м ляв не н ч стт н субективн т или инструмент лн т (неявно з ложен в модел) информ ция. збир се, следв д подчерт ем, че субективн т ч стн модел никог ням д достигне до нул и не бив д се стремим към тов . ов озн ч в, че втор т посок н усъвършенств не н декв тностт и ефективностт н икономико-м тем тическите модели трябв д бъде н сочен към учебно-пр ктическ т подготовк и р звитие н с мия субект н моделир нето.

ретото н пр вление се отн ся до необходимостт от р зр ботв не н принципно нови н чини $з$ използв не в моделите н многообр зн, p знок чествен изходн информ ция з изследв ния обект. съж ление тук съществув т много трудности, някои от които им т инструмент лен х p ктер. $\mathrm{K}$ н пример, тр диционните технологии н моделир нето с ориентир ни обикновено към отчит не н количествен т ст тистическ информ ция и не позволяв т отчит нето н косвен т , к чествен т информ ция, постъпв щ от $\mathrm{p}$ злични източници. руги трудности с свърз ни с р знородностт и р зличн т степен н достоверност н изходн т информ ция. свен тов голямо зн чение им т сведеният относно неопределеностт, вероятностт, зн чимостт, ценностт н р зличните елементи н информ цият, т.е. т.н р. мет информ ция, предн зн чен 3 формиp нето н интересув щ т ни икономическ информ ция.

\section{ключение}

езспорно прил $г$ нето н м тем тически модели спом г 3 по-доброто р 3бир не н същин т н редиц икономически процеси, води до уточняв не и изясняв не н икономическ т терминология и по този н чин до голям степен стимулир р звитиетон с м т икономическ н ук. обре е, об че, д не се прек ляв с прекомерно много увлечения в т зин сок . кономик т к то н ук, политик и пр ктик е изключително сложн и именно т зи сложност е 6 риер т , която м те- 
м тик т не може изцяло д преодолее. други думи к 3 но, изискв ният н икономик т и к то н ук, и К то политик, и к то пр ктик зн чително превиш в т съществув щите н сег шния ет п възможности н м тем тик т . кономическото поведение не вин ги може д се сведе до форм лни процедури. този контекст ст в ясно, че не е възможн пълн м тем тиз ция н икономик т в онзи смисъл, в който проповядв т тов еон лр с и неговите последов тели. ттук ст в ясно, че трябв д сен мерят р зумни гр ници н приложение, в които м тем тическият инструмент риум би бил действително полезен. ези гр ници предв рително не мог т д се посоч т, те се определят от естествения ход н $\mathrm{p}$ звитието н н ук т .

л вното предимство н икономико-м тем тическия модел е точностт н резулт тите, получени по м тем тически път. о тези резулт ти с точни в р мките н с мия м тем тически модел и може д се ок ж т не толков точни спрямо ре лн т икономик.

то основен недост тък н м тем тическите модели може д се посочи недост тъчн т степен н декв тност н повечето от тях н ре лните икономически процеси. $\quad$ ктерното з тези модели е висок т степен н бстр ктност, зн чителн т иде лиз ция и условност н техните конструкции.

ез висимо от посочените недост тъци м тем тическото н пр вление в икономик т зн чително доприн ся з усъвършенств нето н мех низмите н стоп нисв не, регулир не и упр вление н фирмено, отр слово ин цион лно р внище, особено в условият н п з рно стоп нство. нес ролят н м тем тик т в икономическите изследв ния е общопризн т и не се оспорв сериозно почти от никого. н чението н м тем тическото моделир не н р ств и пор ди обстоятелството, че в икономик т е неизгодно, в повечето случ и и невъзможно, д се пр вят експерименти.

\section{итер тур}

1. лекс ндров, . . бщий взгляд н м тем тику.// тем тик, её содерж ние, метод и зн чение. ом I. оскв : 1956.

2. ухолц, . иви идеи от мъртви икономисти. офия: ристо отев, 1993.

3. инер, . . ук и общество. оскв : ук, 1964.

4. ълбр йт, ж. кономическ т н ук в перспектив . ., " ристо отев", 1996.

5. йсън, . тем тик и физик.// спехи физических н ук. 1965.

6. ир к, . ринципы кв нтовой мех ники. оскв : изм тгиз, 1960.

7. кономическ енциклопедия. офия: ук и изкуство, 2005.

8. стория н м тем тик т . офия: ук и изкуство, 1974.

9. ейнс, ж. . бщ теория н 3 етостт, лихв т и п рите. офия: ристо отев, 1993.

10. ендеров, . ръзк т между отделните нещ много често мин в през м тем тик т . ук т - новите тенденции. ъст вител икол й теев. офия: 
вят, 2001.

11. еплер, . тем тик в современном мире. оскв : ысль, 1967.

12. л йн, . тем тик : тр т определености. оскв : ир, 1981.

13. олмогоров, . . тем тик . . зд. 2. ом 26, 1976.

14. ьнев, . и др. икроикономик . вищов, 2007.

15. р тк бълг рск енциклопедия ( ). ом 3. офия: , 1966.

16. еон рдо д инчи. збр нные естественнон учные произведения. ед кция, превод, ст тья и комент рии . . убов . оскв , 1955.

17. еонидов, т." ов т икономик ": модели н пр вителствен политик .

// кономическ мисъл, 2003, № 3.

18. теев, . кономико-м тем тическо н пр вление в икономическите н уки състояние и тенденции. офия: , 1986.

19. ин сян, . кроикономическ политик : пр вил срещу дискреция.

// кономическ мисъл, 2002, № 6.

20. ин сян, . кономическ мисъл: търсене н устойчивост и д птивност.

// кономическ мисъл, 2006, № 5.

21. иркович, . еждун родн икономик . офия: р кия- , 2000.

22. иркович, . олитическ икономия и икономик : критик н ст новищ т

з общото и р зличното между тях. // кономическ мисъл, 2003, № 4.

23. иркович, . олезност и стойност. офия: р кия- , 2005.

24. иркович, . твържд в не н системния подход в икономическ т теория.

// кономическ мисъл, 2006, № 5.

25. иркович, . кономическ т систем . офия: р кия- , 2008.

26. яки, . одели и эксперименты - это одно и то же. // опросы экономики, 2008, № 11.

27. орт, . нституции, институцион лн политик и икономически резулт ти. офия: $\quad 2000$.

28. еченкин, . . соотношении м тем тики и ре льности. // ести моск. унт , сер. 7, илософия, № 4, 2008.

29. нгелов, . онкуренцият в неокл сическия модел н икономическия р стеж. // кономическ мисъл, 2008, № 6.

30. яцк с, . ., л кунов, . . оличественных н лиз в экономике. оскв : ук, 1987.

31. озен, . . ель-оптим льность-решение. тем тические модели принятия оптим льных решений. оскв : дио и связь, 1982.

32. ыбников, . . стории м тем тики. ом II. оскв : , 1961.

33. довский, . . ксиом тический метод построения н учного зн ния. // илософские вопросы современной форм льной логики. оскв , 1962.

34. елегмен, . сновные течения современной экономической мысли. оскв : рогрес, 1968.

35. мит, - ог тството н н родите. офия: ртизд т, 1983. 
36. тойков, т. кономико-м тем тически модели. // тем тик , 1970, кн. 3.

37. зунов, т. и др. икроикономик . офия: орекс рес, 2003.

38. имев, . вклид. // тем тик , 1969, кн. 2.

39. ляпин, . . еория три ды цикличного р звития. // борникст тей. оскв , 2003.

40. умпетер, - стория н икономическия н лиз. ом II. офия: розорец, 1999.

41. йнштейн, . обр ние н учных трудов. оскв : ысль, 1966.

42. Backhouse, R. E. If Mathematics is Informal, Then Perhaps We Should Accept That Economics Must Be Informal Too. // Economics Journal, 1998, Vol. 108, № 451.

43. Baumol, W. J. Economic Theory and Operations analysis. London, 1961.

44. Friedman, M. The methodology of positive economics. Appraisal and criticism in economics: A book of readings. Boston etc., 2001.

45. Kleiner, G. B. Economic and mathematical methods and economic theory. // кономик и м тем тические методы. ом 37, 2001, № 3.

46. Lukas, R. Jr. Methods and problems in business cycle theory. // Journal of Money, Credit and Banking, 1980, Vol. 12, № 4.

47. Newman, J., O. Morgenstern. Theory or Games and Economic Behavior. Princeton University Press, 1953.

\title{
MATHEMATICS AND ECONOMICS
}

Prof. Dr Ec. Sc. Boyko Atanasov Assoc. Prof. Dr Plamen Iliev

\begin{abstract}
In the study there are drawn and discussed some issues, connected with the rationalization of the nature and process of mathematical cognition with respect to the following: the subject and peculiarities of mathematics, the kinds of abstraction in mathematics, the methods of idealization, formalization and axiomatization. There is presented the specific role of the practice in the development of mathematics, the criteria for the genuineness of mathematical knowledge, some objective laws in the historical development of mathematics.

Special treatment is given to the mathematization of natural sciences and the practice as one of the leading tendencies in the development of contemporary science. There is put forward the idea, that the main cause for the process of mathematization is found above all in the qualitative growth in scientific knowledge. Of course the reason for the possibility to apply mathematics is hidden also in the development of mathematics itself, the latter offering adaptive mathematical mechanism, capable of studying quantitative interdependencies in the new spheres of the real world.

There is made an attempt at drawing the factors and possibilities for applying the mathematical tools in economics. There is emphasized the fact, that the need for specific study tools within economics itself as scientific knowledge calls for the intensive use of mathematics in economic theory.

The study pays particular attention to the need to build, test and use economic-mathematical models at the current stage of the economic development, characterized above all by the transition to the knowledge economy. In this context, in the study there is made an attempt, on the basis of the results that have been achieved, to outline the new concept of the role and place of economicmathematical models in the system of theoretical and applied economic research, broadening the traditional views on the mathematical model as a tool for economic analysis.
\end{abstract}




\title{
MATHEMATIK UND WIRTSCHAFT
}

\author{
Prof. Dr. W. W. Boiko Atanasov \\ Doz. Dr. Plamen Iliev
}

\section{Zusammenfassung}

In der Studie werden Fragestellungen entwickelt und untersucht, die sich auf den Charakter und den Entwicklungsprozess des mathematischen Wissens beziehen, und zwar mit folgenden Schwerpunkten: Gegenstand und Besonderheiten der Mathematik, Arten von mathematischen Abstraktionen, Methoden der Idealisierung, Formalisierung und Axiomatisierung. Dargelegt werden die spezifische Rolle der Praxis in der Entwicklung der Mathematik, die Kriterien für die Wahrhaftigkeit des mathematischen Wissens sowie bestimmte Gesetzmäßigkeiten der historischen Entwicklung der Mathematik.

Besondere Beachtung findet die Mathematisierung der Naturwissenschaften und der Praxis als eine grundlegende Tendenz der modernen Entwicklung der Wissenschaft. Es wird die Idee vertreten, dass der hauptsächliche Grund für die fortschreitende Mathematisierung vor allem im qualitativen Wachstum der wissenschaftlichen Kenntnisse besteht. Die Möglichkeiten für den Einsatz der Mathematik sind allerdings auch durch die Entwicklung der Mathematik selbst entstanden, infolgedessen die Mathematik ein flexibles Instrumentarium bietet, das quantitative Zusammenhänge in den neuen Bereichen der Wirklichkeit zu untersuchen vermag.

Es wird der Versuch unternommen, Voraussetzungen und Einsatzmöglichkeiten des mathematischen Instrumentariums für die Wirtschaft zu entwickeln. Ein Akzent ist, dass das Bedürfnis nach einem spezifischen Instrumentarium für Untersuchungen innerhalb der Wirtschaftswissenschaft $\mathrm{zu}$ einem intensiven Einsatz mathematischer Methoden in der Wirtschaftstheorie führt.

In der Studie findet die Notwendigkeit besondere Beachtung, dass auf dem heutigen Stand der wirtschaftlichen Entwicklung mit starkem Trend zu einer Wirtschaft des Wissens ökonomisch-mathematische Modelle gebaut, versuchsweise eingesetzt und praktisch angewendet werden. In diesem Zusammenhang bemüht man sich in der Untersuchung darum, auf der Grundlage von erzielten Ergebnissen ein neues Konzept über die Rolle und die Bedeutung der ökonomisch-mathematischen Modelle im System der theoretischen und angewandten Wirtschaftsuntersuchungen aufzuzeigen, indem man über traditionelle Vorstellungen über mathematische Modelle als Instrument der Wirtschaftsanalyse hinausgeht. 


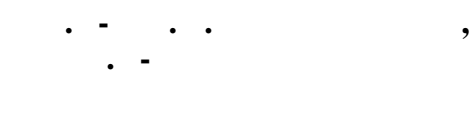

p зр ботке p ссм трив ются вопросы, связ нные с осмыслением х р ктер и процесс м тем тического позн ния относительно предмет и особенностей м тем тики, видов бстр кций в м тем тике, методов иде лиз ции, форм лиз ции и ксиом тиз ции. зл г ются специфическ я роль пр ктики р звития м тем тики, критерии истинности м тем тических зн ний, некоторые 3 кономерности исторического р звития м тем тики.

деляется особое вним ние м тем тиз ции естественных н ук и пр ктики к к ведущей тенденции р звития современной н уки. ыдвиг ется идея, что основн я причин процесс м тем тиз ции прежде всего в к чественном росте н учного позн ния. зумеется, возможность применения м тем тики вытек ет т кже из р звития с мой м тем тики, котор я предл г ет д птивный пп р т, способный исследов ть количественные вз имосвязи в новых сфер х ре льного мир .

редпринят попытк обоснов ть предпосылки возможностей применения м тем тического инструмент рия в экономике. кцентируется н том, что необходимость специфического инструмент рия исследов ния в с мой экономике в к честве н учного позн ния обусл влив ет интенсивное использов ние м тем тики в экономической теории.

p зр ботке фиксируется вним ние н необходимости построения, экспериментиров ния и использов ния экономико-м тем тических моделей н нынешнем эт пе экономического p звития, $\mathrm{x}$ р ктеризующемся прежде всего к экономике позн ния. этом контексте в исследов нии сдел н попытк н 6 зе достигнутых результ тов определить новую концепцию роли и мест экономико-м тем тических моделей в системе теоретических и прикл дных экономических исследов ний посредством р сширения тр диционных предст влений о м тем тических моделях в к честве инструмент экономического н лиз .

\section{ьдърж ние}

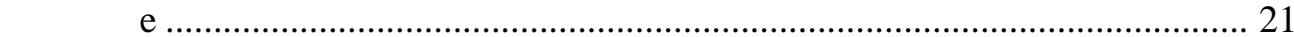

1. якои спекти н методологият н м тем тик т ...................................... 22

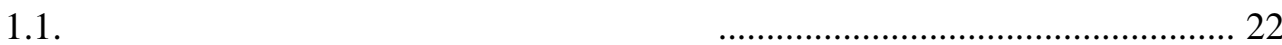

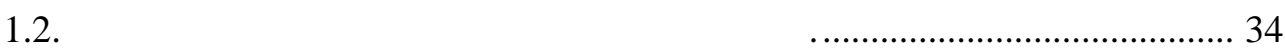

2. редпост вки 3 приложимост н м тем тик т в икономик т ................43

2.1. кономик т к то обект н м тем тическо моделир не ....................... 43

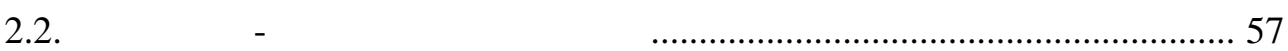

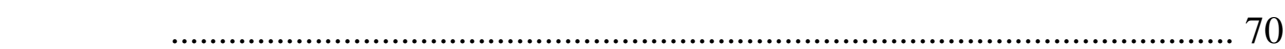

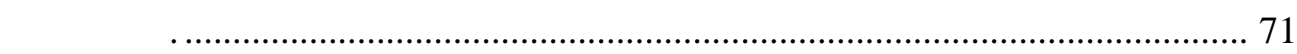

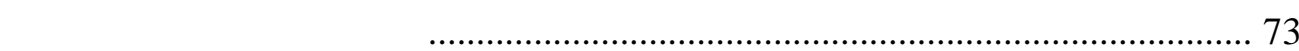

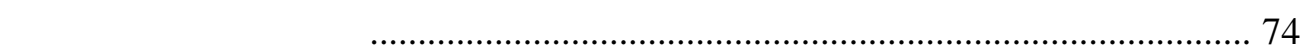

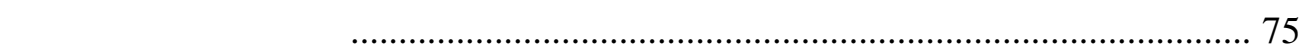

